\title{
Overcoming challenges in the classification of deep geothermal potential
}

\author{
K. Breede, K. Dzebisashvili, and G. Falcone \\ Dept. of Geothermal Engineering and Integrated Energy Systems, Institute of Petroleum Engineering, Clausthal \\ University of Technology, Clausthal, Germany \\ Correspondence to: K. Breede (katrin.breede@tu-clausthal.de)
}

Received: 23 June 2014 - Revised: 17 February 2015 - Accepted: 24 February 2015 - Published: 7 April 2015

\begin{abstract}
The geothermal community lacks a universal definition of deep geothermal systems. A minimum depth of $400 \mathrm{~m}$ is often assumed, with a further sub-classification into middle-deep geothermal systems for reservoirs found between 400 and $1000 \mathrm{~m}$. Yet, the simplistic use of a depth cut-off is insufficient to uniquely determine the type of resource and its associated potential. Different definitions and criteria have been proposed in the past to frame deep geothermal systems. However, although they have valid assumptions, these frameworks lack systematic integration of correlated factors. To further complicate matters, new definitions such as hot dry rock (HDR), enhanced or engineered geothermal systems (EGSs) or deep heat mining have been introduced over the years. A clear and transparent approach is needed to estimate the potential of deep geothermal systems and be capable of distinguishing between resources of a different nature. In order to overcome the ambiguity associated with some past definitions such as EGS, this paper proposes the return to a more rigorous petrothermal versus hydrothermal classification. This would be superimposed with numerical criteria for the following: depth and temperature; predominance of conduction, convection or advection; formation type; rock properties; heat source type; requirement for formation stimulation and corresponding efficiency; requirement to provide the carrier fluid; well productivity (or injectivity); production (or circulation) flow rate; and heat recharge mode. Using the results from data mining of past and present deep geothermal projects worldwide, a classification of the same, according to the aforementioned criteria is proposed.
\end{abstract}

\section{Review}

In the past, definitions such as hydrothermal and petrothermal have been created to categorize deep geothermal systems, i.e. systems with a depth greater than $400 \mathrm{~m}$, into two groups. The first group includes geothermal reservoirs that provide a heat source, a natural reservoir with high enough permeability, and a water recharge. The second group comprises geothermal systems where only a natural heat source exists, while the underground heat exchanger must be created artificially and water must be supplied for water circulation within. Hydrothermal systems (HSs) are clearly dominant in comparison to petrothermal systems (PSs) with regards to number of occurrences worldwide and megawatts of electricity generated.

In 1970, the hot dry rock (HDR) concept was introduced to describe a system which uses hot and dry rock as a heat source and where an artificial underground heat exchanger had to be created (Cummings and Morris; 1979; Tester et al., 1989; Potter et al., 1974). However, during the history of deep drilling, it was found that most rocks are actually not completely dry, but contain at least some naturally occurring water. This finding led to the development of a definition of hot wet rock (Duchane, 1998). In addition, the category of hot fractured rock was created to describe geothermal reservoirs that consist of hot rocks, typically crystalline, that are already naturally fractured due to fault systems or that require artificial fracturing (Genter et al., 2003). Stimulated geothermal systems, deep heat mining (Häring, 2007), and deep earth geothermal were also introduced to describe deep geothermal systems that are typically created in crystalline rocks and are independent from water-bearing structures. All these definitions are actually related to PSs. 
Recently, the new definition of enhanced or engineered geothermal systems (EGSs) was introduced for deep geothermal systems, which required technical enhancement such as stimulation to create an artificial reservoir or the supply of water (MIT, 2006a; AGRCC, 2010; Williams et al., 2011; BMU, 2011). This definition is not solely related to PSs, but can also be applied to HSs that require technical enhancement such as stimulation techniques or artificial water supply for water circulation in order to increase the productivity of the system.

On the hydrothermal side of deep geothermal systems, only the recently developed definition of hot sedimentary aquifer (HSA) was additionally introduced to describe HSs as having a heat source that is conduction-dominated, rather than convection-dominated.

However, the creation of so many definitions for deep geothermal systems and the fact that they are not recognized as internationally standards has created some confusion about the actual classifications and which geological setting or geothermal system is being described. An additional complication is that, at a given geothermal site, different systems can exist; e.g. at Soultz-sous-Forêts, where at one depth, an HFR system is present, and at another depth, an HDR system is found.

This paper tries to meet the challenge of the classification of deep geothermal systems by reintroducing the categories of petrothermal, hydrothermal and, additionally, HSA. The term EGS is excluded from our new classification as it carries a vague definition and provides insufficient information about the system, e.g. if natural water is available in the underground heat exchanger and if the permeability is high enough to produce heat or electricity.

\section{Definition of deep geothermal energy}

Deep geothermal energy is defined by its depth, which has to be at least $400 \mathrm{~m}$ and a temperature of at least $20^{\circ} \mathrm{C}$. However, some authors recommend using the term deep geothermal energy only for depths of at least $1000 \mathrm{~m}$ and temperatures of more than $60^{\circ} \mathrm{C}$. The depth range from 400 to $1000 \mathrm{~m}$ is sometimes referred to as middle-deep geothermal. Deep geothermal systems are commonly divided into HSs and PSs, but deep geothermal energy can also be used from mines, caverns, and tunnels. (PK Tiefe Geothermie, 2007; VDI-Richtlinie 4640, 2010)

\subsection{Definition of enhanced geothermal systems}

In recent times, the term EGS has been used more and more. However, as already reported by Breede et al. (2013), the definition of EGS is vague and exists in different forms. For example, MIT (2006a) defines EGSs as "engineered reservoirs that have been created to extract economical amounts of heat from low permeability and/or porosity geothermal resources". Another definition is provided by the Australian
Geothermal Reporting Code Committee, which defines an EGS as "a body of rock containing useful energy, the recoverability of which has been increased by artificial means such as fracturing" (AGRCC, 2010).

\subsection{Definition of petrothermal systems}

The terminology petrothermal was first mentioned by Roberts and Kruger (1982), while the term EGS was first proposed by Grassiani et al. (1999). Petrothermal systems (PSs) are commonly defined as hot $\left(>150^{\circ} \mathrm{C}\right)$ and dry crystalline or dense sedimentary rocks, which do not have high enough natural permeability and therefore require the application of stimulation techniques in order to create an artificial reservoir (Nag, 2008). Hence, these systems are independent from water-bearing structures and it is essential to provide water for both hydraulic fracturing and as a carrier fluid (via water injection for circulation through the underground heat exchanger, and subsequent production). The natural permeability of the production well before stimulation, as opposed to the injection well, defines the term petrothermal (Schulz, 2008); thus, the injection horizon could be an aquifer, which can be used for water disposal. By this definition, Landau in Germany is not a PS, but an HS, as hydraulic fracturing was only required for the injection well in order to increase the injectivity index (Schindler et al., 2010). However, in many geothermal projects, the injection well and production well have the same technical design. Thus, they can be used alternatively as injector or producer, according to the hydraulic schemes. This is the case at Soultz, for example, where some wells were first used as producers and then as injectors. In order to create the artificial heat exchanger and to use the PS, at least two wells, one injection well and one production well, are required.

Schulz (2008) and Kreuter (2011b) state that the following criteria have to be fulfilled simultaneously in the case of a PS:

1. average natural permeability, before stimulation, of less than $10^{-14} \mathrm{~m}^{2}$;

2. production well does not allow for an economically relevant production; i.e. the productivity index is less than $10^{-2} \mathrm{~m}^{3} /(\mathrm{MPa} s)$, without the application of stimulation techniques;

3. using hydraulic fracturing, the production of the formation must be increased by at least $50 \%$.

In his second draft for the renewable energy law in Germany (EEG), Schulz (2009) recommended that the productivity enhancement factor should be $100 \%$ (a factor of 2) instead of only $50 \%$ (a factor of 1.5). How high this factor should be depends on the determined productivity index prior to hydraulic fracturing and is thus site dependent. The idea behind the enhancement factor is that the productivity must be increased in such a way that it is economical to produce geothermal 
energy at the given site. The productivity index has to be determined using hydraulic tests before any hydraulic fracturing techniques are applied. However, prior application of chemical stimulations is possible.

The values for the permeability threshold, productivity index and the productivity enhancement factor of $50 \%$ are based on field experience, mainly gathered from the European HDR project at Soultz-sous-Forêts in France. However, it is difficult to generalize from this site alone, as different productivity indices have been determined at different depths varying from 1 to more than 100 (Schill et al., 2013). Thus, the complexity of the geological conditions has to be taken into account before determining which productivity enhancement factor is suitable for a given formation.

When considering past nomenclature, PSs could fall into the following categories $(\mathrm{GtV}, 2014 \mathrm{c})$ :

- enhanced geothermal systems (EGSs),

- engineered geothermal systems (EGSs),

- hot dry rock (HDR),

- hot wet rock (HWR),

- deep heat mining (DHM),

- stimulated geothermal systems (SGSs),

- deep geothermal probes.

PSs are used most commonly for electricity generation (Hirschberg et al., 2015a) and combined heat and power (CHP) production due to drilling costs being much higher than for HSs. However, with increasing costs for heating oil, PSs could also become economic for heating in the future. The exception is the deep geothermal probe, which is a closed-loop system that employs a heat transfer medium to recover heat being stored in any rock formation. Geothermal probes are used for heating purposes only.

PSs are always conduction-dominated (Sass and Goetz, 2011); i.e. the heat moves through the material from a hotter zone to a cooler zone.

There exists a transition zone between HSs and PSs, where a project could be classified as either petrothermal or hydrothermal. Thus, at the same geothermal site, different geothermal systems can co-exist at different depths, as it is the case for Soultz and Landau. Experience gained from deep wells showed that the classic definition of the HDR Technology, which refers to a hot and almost completely dry basement rock, is invalid (Schulz, 2008).

\subsection{Definition of hydrothermal systems}

Hydrothermal systems (HSs) are defined by the availability of a water-bearing structure, such as an aquifer, which is used by the production and injection well (Bertani, 2012). To ensure high enough flow rates and thus high productivity of the wells, high permeabilities are required and the waterbearing structure should be vertically and laterally extensive to guarantee the sustainability of the $\mathrm{HS}$ ( $\mathrm{GtV}, 2014 \mathrm{~d})$. Looking at the definition of PS proposed by Schulz (2008), the permeability of the productive horizon in HSs should be at least $10^{-14} \mathrm{~m}^{2}$ and the productivity index at least $10^{-2} \mathrm{~m}^{3}$ /(MPa s). Thus, HSs are convection-dominated; i.e. the heat is transported by the movement of hot material (Huenges, 2010a). Volcanic systems are the most representative type of HSs worldwide. Additional common hydrothermal reservoir rocks are sedimentary porous aquifers, such as sandstones or conglomerates, secondary fractured and/or cavernous rocks, such as limestones, or young and deep fault systems, such as those found in the Upper Rhine Valley (Huenges, 2010b; GtV, 2014d). Often major fault zones are targeted for HSs, as they commonly provide much higher permeability values. However, due to the existing prestresses, these fault zones might present more risk for induced seismicity than initially estimated (Hirschberg et al., 2015b). Typically, hydrothermal reservoirs in Germany are found in the North German Basin, the Upper Rhine Graben and the Molasse Basin, located in the north, south-west and south of Germany, respectively.

Besides the original exploration well in a HS field, at least one further appraisal well must be drilled. In some cases, an additional third well is drilled to reduce hydro-mechanical shearing in the reservoir, which thereby reduces the risk of induced seismicity (Cuenot, 2013). Although HSs do not require stimulation, Huenges (2010c) states that it might be sensible to use chemical stimulation in order to enhance permeability in the near-wellbore region.

\subsection{Definition of hot sedimentary aquifers}

In recent years, the term HSA has been created for deep and hot sedimentary aquifers that are, in contrast to common HSs, conduction-dominated (Mortimer et al., 2010; Huddlestone-Holmes and Hayward, 2011; HuddlestoneHolmes and Russel, 2012). However, Clean Energy Australia (2014) refers to HSA systems as convective systems. Various minimum temperatures are given by different authors: $75^{\circ} \mathrm{C}$ (cleanenergyaus, 2014), $130^{\circ} \mathrm{C}$ (Huddlestone-Holmes and Russel, 2012), $140^{\circ} \mathrm{C}$ (Barnet, 2009). Also, different depths are proposed: 1 to $3 \mathrm{~km}$ (cleanenergyaus, 2014); 2.5 to $3 \mathrm{~km}$ (newworldenergy, 2014). A maximum depth of $4.5 \mathrm{~km}$ was given by Huddlestone-Holmes and Russel (2012), reflecting that the likelihood that the permeability would be too low at greater depths. The Australian Energy Resource Assessment states that the depth should be "shallow enough for natural porosity and permeability to be preserved so that fluid circulation can occur without artificial enhancement". Although, stimulation techniques are not required, they might be applied to increase the near-wellbore permeability (Huddlestone-Holmes and Hayward, 2011). However, this statement does not clearly indicate which type of stim- 
ulation would be required below $4.5 \mathrm{~km}$, although it is most likely to be hydraulic fracturing.

Specific values could neither be found for porosity, permeability nor for flow rates. The permeability of HSA systems can either be matrix permeability in sandstone or fracture permeability in tight limestones or fault zones (HuddlestoneHolmes and Hayward, 2011). Huddlestone-Holmes and Russel (2012) state that the rock density should be lower than the crystalline basement rocks, which are targeted for HDR or EGS resources, and should be around $2400 \mathrm{~kg} \mathrm{~m}^{-3}$.

Another requirement is that the reservoir must be covered by a thick cap rock made of clay and/or coal rich sequences, which acts as a thermal insulator (Mortimer et al., 2010). This is also the case for volcanic HSs and true for all geothermal systems, as the cap rock significantly reduces heat loss.

For HSA systems in Australia, newworldenergy (2014) states that at least one of the following geological settings should be fulfilled:

- Radioactive decay in basement rocks acts as a heat source for overlying aquifers

- Remnant heat from old volcanic centres ensures an elevated geothermal gradient

- Hot water welling up from deep basins along thermal density and/or pressure gradients

- Rapid tectonic uplift brought a deep hot water formation closer to the surface and compressed the geothermal gradient.

\section{Stimulation techniques}

Stimulation techniques such as hydraulic stimulation, chemical stimulation, and thermally induced fracturing are commonly used to enhance the permeability of geothermal reservoirs, thereby increasing their productivity, to create new fractures and hence an artificial underground heat exchanger, or to clean the wells of drill cuttings. The selection of the most appropriate stimulation technique depends on, among other parameters, the desired depth of invasion, i.e. the radius of influence.

The most common stimulation technique is hydraulic stimulation, as it provides the largest depth of invasion and can be applied to re-open and/or create fractures up to several hundreds of metres away from the borehole (ENGINE, 2008b). Fractures generated by hydraulic stimulation can be tensile (perpendicular to minimum principal stress axis), shear (perpendicular to maximum principal stress axis), or a combination of both, and their orientation and distribution depends on the overall stress field (Zimmermann et al., 2010a). In some cases, it is recommended to isolate intervals in the wells and perform consecutive stimulations of these intervals rather than carrying out a massive hydraulic stimulation. This is an expedient to reduce the risk of creating shortcuts and larger seismic events (ENGINE, 2008b). Hydraulic stimulation is a requirement for the creation of an artificial petrothermal heat exchanger.

An example of quantitative values for evaluating the impact of hydraulic fracturing in matrix-dominated formations and correlating input/output parameters is given by Groß Schönebeck. Three hydraulic stimulation treatments were carried out separately in a well over 6 days: the cyclic waterfrac treatment in the low permeable volcanic rocks and gel-proppant treatments in the lower and upper Dethlingen sandstones. For the waterfrac treatment, $13170 \mathrm{~m}^{3}$ of fluids and 24.4 tons of quartz sand (the latter as proppant) were injected. The maximum wellhead pressure of 58.6 MPa was reached at the maximum flow rate of $9 \mathrm{~m}^{3} \mathrm{~min}^{-1}$, with the total duration of the treatment being $6389 \mathrm{~min}$. (Zimmermann et al., 2010a). After the isolation of this section with a bridge plug at $4300 \mathrm{~m}$ for the first and at $4123 \mathrm{~m}$ for the second treatment, two gel-proppant treatments in highly permeable sandstones were performed over 4 days. In total, 95 tons of proppants and $280 \mathrm{~m}^{3}$ of cross-linked gel were injected into the lower Dethlingen formation with a flow rate of $4 \mathrm{~m}^{3} \mathrm{~min}^{-1}$ and 113 tons of proppants for the first treatment; $310 \mathrm{~m}^{3}$ of cross-linked gel were injected into the upper Dethlingen formation at flow rates ranging from $3-3.5 \mathrm{~m}^{3} \mathrm{~min}^{-1}$ for the second treatment (Zimmermann et al., 2010b). The production test, which lasted $11.8 \mathrm{~h}$ and produced about $356 \mathrm{~m}^{3}$ of fluids, showed an overall productivity increase after the stimulations by more than a factor of $4.30 \%$ of the total flow came from the volcanic rocks and $70 \%$ from the sandstones (Zimmermann et al., 2010a). However, it can be argued that hydraulic fracturing in matrix-dominated formations is not the most common situation in deep geothermal projects.

Another example of hydraulic performance improvement of a PS through hydraulic fracturing is given by the Fenton Hill project, which has been referred to as a PS by Kruger (1990). In the second phase of this PS, a total fractured volume of $1 \mathrm{~km}^{3}$ was created, flow rates were increased up to $18.5 \mathrm{Ls}^{-1}$, and the permeability was improved to a value of 3 to $5 \mathrm{~m}^{2}$ (MIT, 2006f).

Of course this is only one example; a case-by-case investigation of the geomechanics involved must be carried out to estimate the benefit of hydraulic stimulation. In some cases, the productivity index can be much higher than reported above. Schindler et al. (2010), for example, quote productivity improvement by a factor of 20 after massive hydraulic stimulations in crystalline rocks.

Jung (2013) presented an overview of different hydraulic stimulation techniques used for EGSs, such as multi-zone hydraulic fracturing in crystalline basements (based on the original HDR concept), multi-zone massive injection in naturally fractured crystalline rock formations (in order to generate multiple wing cracks), and open-hole massive injection in naturally fractured crystalline rock formations.

The second most common stimulation technique is chemical stimulation, which is applied to enhance the permeability 
in the near-wellbore region, i.e. up to a distance of few tens of metres (ENGINE, 2008b). This technique is also called acidizing as acids such as hydrochloric acid (HCL) and hydrofluoric acid (HF) are commonly used to react with carbonates and silicates, respectively. The only additives that might be used for geothermal systems are as follows: corrosion inhibitor, inhibitor intensifier, and high-temperature iron-control agent (ENGINE, 2008b). According to Schumacher and Schulz (2013), acidizing with HCL can significantly improve the performance of a geothermal well drilled into carbonate rock. In addition, it is an effective means to remove fine materials from the walls of the wells, i.e. to clean the well from drill cuttings and from scaled minerals that decrease permeability (Schumacher and Schulz, 2013; ENGINE, 2008b). The aim of acidizing in sandstones is to dissolve naturally occurring clay or material that originated from drilling and completion works and other plugging minerals in the near-wellbore region, thereby increasing the permeability (ENGINE, 2008b). In this case, the acidizing is performed in three stages: pre-flush (HCL), main flush (HCL-HF mixture) and overflush (HCL, or KCL, $\mathrm{NH}_{4} \mathrm{CL}$ or fresh water) (ENGINE, 2008b). Chemical stimulation can be applied to any of the following deep geothermal systems: HS, HSA, PS, EGS.

Schumacher and Schulz (2013) analysed improvements after several acidizing steps in a number of wells in the carbonate rocks of the south German Molasse Basin; their findings are relevant for analogue geothermal projects worldwide. The normalized flow rate for these wells was taken as $10 \mathrm{~L} \mathrm{~s}^{-1}$, with an observed improvement of over $10 \%$ per $\mathrm{m}^{3}$ of $15 \% \mathrm{HCL}$ used. The analyses indicate that the first acid treatment significantly increased the productivity, whereas subsequent treatments did not have such a great impact any more, and in some cases resulting in deterioration of well performance.

Thermal fracturing is used in volcanic rock environments, such as found in Iceland, to increase the permeability of existing flow paths, to create new ones, and is achieved with a combination of induced temperature and pressure changes (ENGINE, 2008b). It is used when the temperature difference between injected fluid and rock formation is significant (Flores et al., 2005). Tulinius et al. (2000) provide some quantitative values for this type of stimulation for a $2500 \mathrm{~m}$ deep well in geothermal area of Bouillante, France, which was characterized by low steam output before stimulation. A $253^{\circ} \mathrm{C}$ reservoir was stimulated in periods up to $72 \mathrm{~h}$ using seawater mixed with an inhibitor to prevent anhydrite scaling at a flow rate up to $25 \mathrm{~L} \mathrm{~s}^{-1}$ and initial wellhead pressure of 2.5 MPa, which decreased gradually and was close to zero for maximum injection at the end of the programme. The thermally induced fracturing resulted in a $50 \%$ increase of productivity.

\section{Systematic overview of past and present deep geothermal systems}

The following review consisting of PSs and HSA systems is not meant to be exhaustive, as it is based solely on information that is available in the public domain. This review excludes conventional HSs, because the focus of this paper is on PSs and HSA systems in relation to the widespread term EGS. The overview is divided into PS (see Tables 13 ) and HSA (see Tables 4-6). The PS database consists of 26 projects worldwide, whereas the HSA database consists of 10 projects. Conventional HSs, such as volcanic systems or vapour-dominated systems, are not presented in the tables.

Wherever the literature did not state whether a given project is a PS or an HSA system, and when the present authors did not agree with the classification offered by the literature, an independent view was taken.

Whether the heat source of a project was conductiondominated or convection-dominated was difficult (and in most cases impossible) to find in the literature in order to differentiate HSs from HSA systems.

The databases for PSs and HSA systems are each divided into three parts: general information, petrophysical properties, and operational characteristics.

Table 1 (PS), resp. Table 4 (HSA), comprises general information about PSs, resp. HSA, such as location, operator, description, start date, end date, status, well depth, and distance between producer and injector at depth. The description contains the main goal of each project, whereas the status informs whether a project is still under development, ongoing, concluded, or abandoned.

Table 2 (PS), resp. Table 5 (HSA), presents petrophysical properties of the reservoir such as rock type, porosity, permeability or transmissivity, and temperature. However, only a few porosity and permeability values could be found in the literature. Permeabilities are given in $\mathrm{m}^{2}$. In the case of permeabilities given in Darcy, the values were converted into $\mathrm{m}^{2}$ under the assumption of the presence of fresh water and temperatures of only $10^{\circ} \mathrm{C}$, which the authors admit is an oversimplification. In some cases, only transmissivities were available, which were converted into permeabilities in the cases where reservoir thicknesses were available in the public domain.

Table 3 (PS), resp. Table 6 (HSA) shows operational characteristics such as flow rate, stimulation technique, seismic event, type of power plant, installed electrical capacity, thermal capacity, and flow assurance problems. In most cases, the production flow rate was given. However, in some cases, only injection flow rates could be found in the literature. Stimulation techniques state whether stimulation was applied or not and, in the cases where stimulation was performed, the method that was applied is given. Whenever the information was available in the public domain, it was differentiated in the tables which type of hydraulic stimulation was applied. In the case of missing differentiation in the refer- 


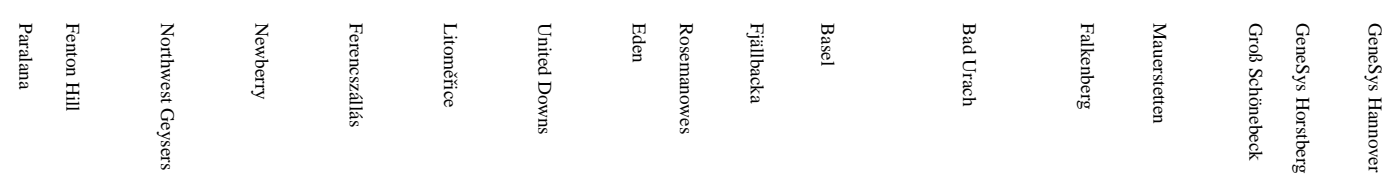

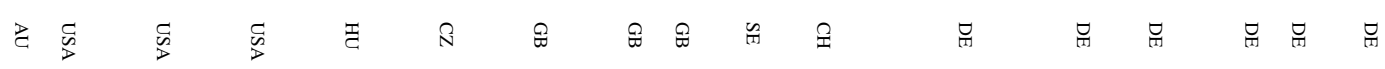
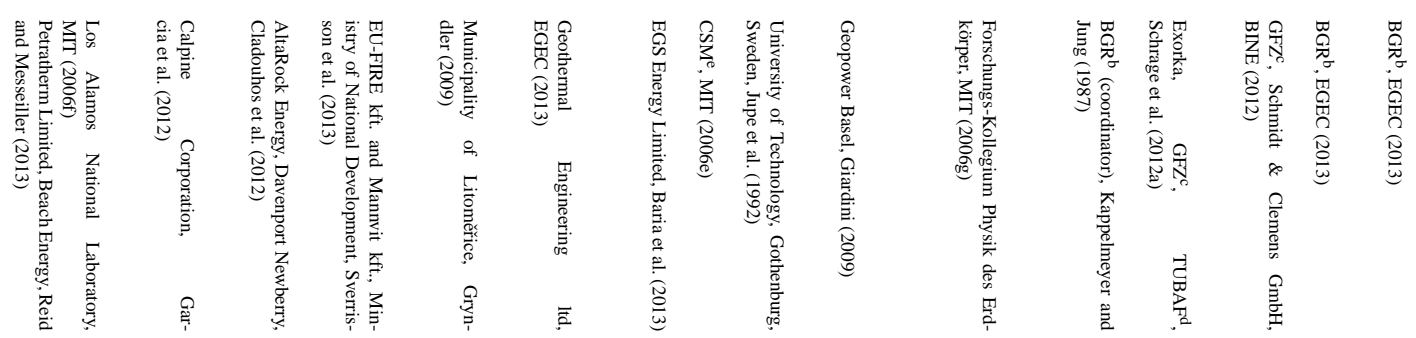

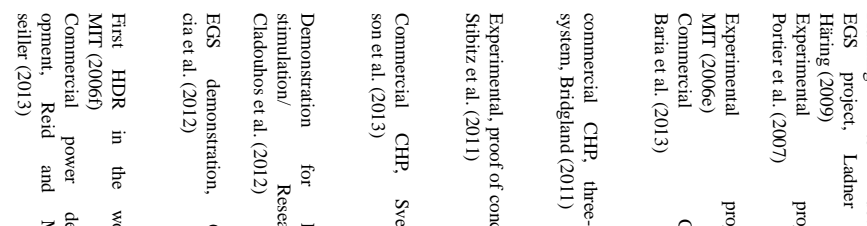

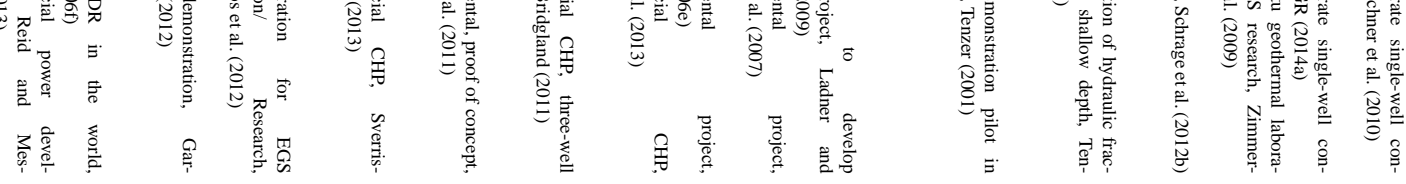

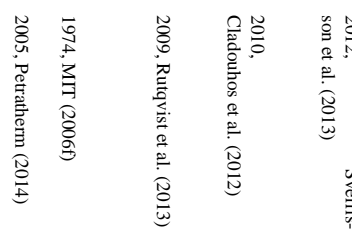

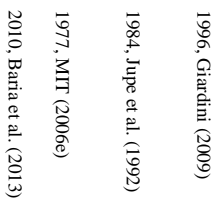

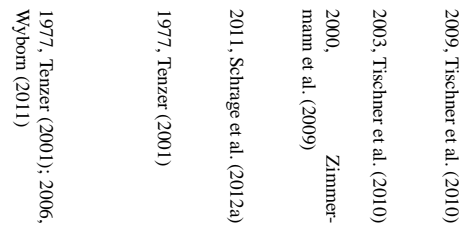

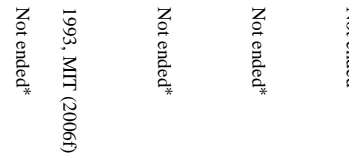

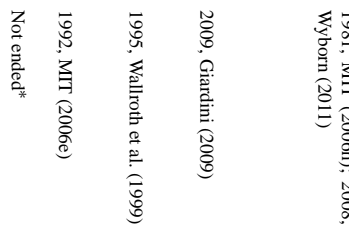

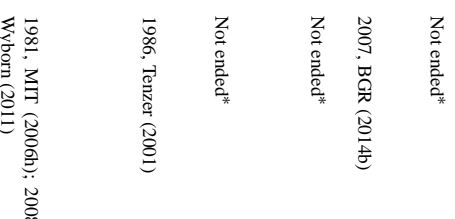

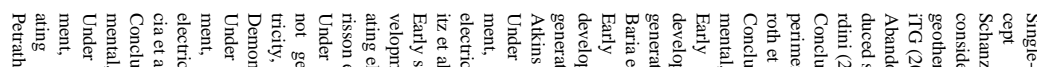

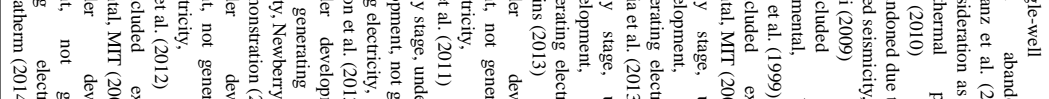

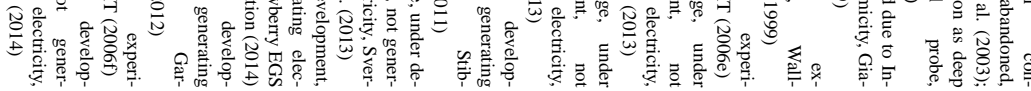

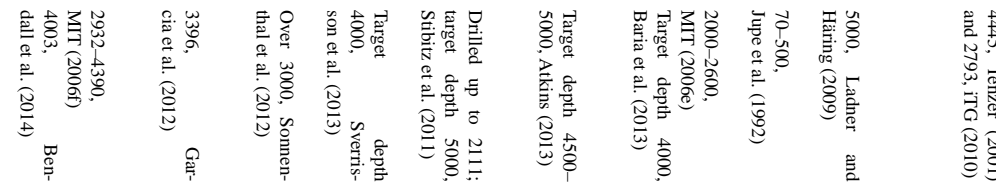

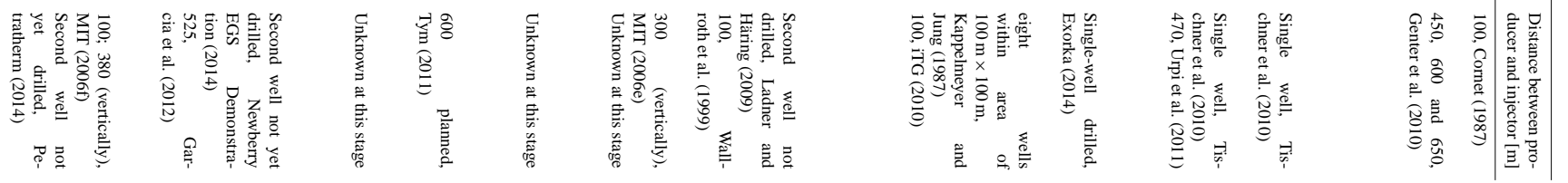

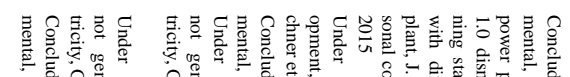

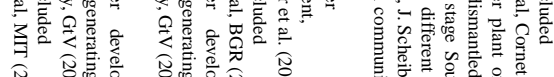

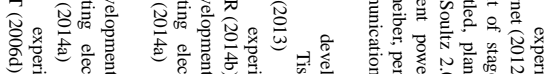




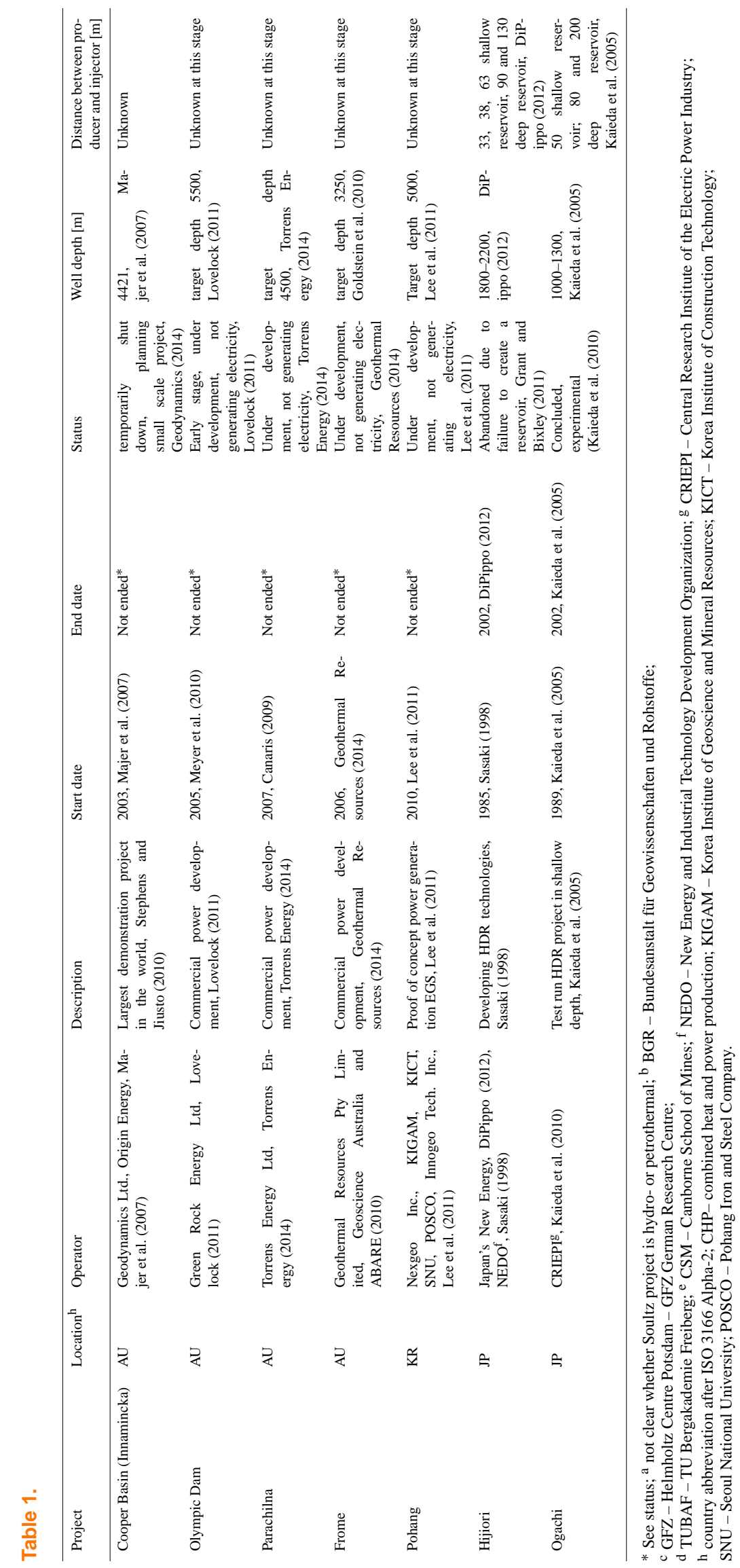


Table 2. Petrophysical properties of petrothermal systems.

\begin{tabular}{|c|c|c|c|c|}
\hline Project & Rock type & Porosity & $\begin{array}{l}\text { Permeability (K) }\left[\mathrm{m}^{2}\right] / \text { transmissivity }(\mathrm{T}) \\
{\left[\mathrm{m}^{2} \mathrm{~s}^{-1}\right]}\end{array}$ & BHT/Reservoir temperature $\left[{ }^{\circ} \mathrm{C}\right]$ \\
\hline Le Mayet & Granite, Cornet (2012) & Unknown & Unknown & 22, Wyborn (2011) \\
\hline Soultz ${ }^{\mathrm{a}}$ & Granite, MIT (2006c) & $\begin{array}{l}\text { Altered rock: } 0.25 \text {, Ledésert et al. (2010); } \\
\text { connected porosity: } 0.0025-0.003 \text {, Portier } \\
\text { and Vuataz (2009) }\end{array}$ & $\begin{array}{l}\text { Fresh Soultz granite: } \quad K=4 \times 10^{-19} \text {, } \\
\text { Ledésert et al. (2010) }\end{array}$ & 200, Genter et al. (2010) \\
\hline GeneSys Hannover & $\begin{array}{l}\text { Bunter sandstone, Tischner } \\
\text { et al. (2013) }\end{array}$ & $<0.1$, ENGINE $(2008 a)$ & $\mathrm{K}=10^{-18}$, Tischner et al. (2013) & 169, Tischner et al. (2013) \\
\hline GeneSys Horstberg & $\begin{array}{l}\text { Bunter sandstone, Tischner } \\
\text { et al. (2010) }\end{array}$ & 0.03-0.11, Orzol et al. (2005) & $\mathrm{K}^{\mathrm{i}}<40 \times 10^{-15}$, GeneSys Hannover (2014a) & 150, Tischner et al. (2010) \\
\hline Groß Schönebeck & $\begin{array}{l}\text { Sandstone and andesitic } \\
\text { volcanic rocks, Zimmer- } \\
\text { mann et al. (2009) }\end{array}$ & 0.08 to 0.10 , Zimmermann et al. (2010a) & $\begin{array}{l}\mathrm{K}^{\mathrm{i}}=10^{-14} \text { to } 10^{-13}, \text { Zimmermann } \\
\text { et al. }(2009) ; \mathrm{K}^{\mathrm{i}} \text { up to } 16.5 \times 10^{-15} \text {, } \\
\text { Zimmermann et al. (2010a) }\end{array}$ & 150, Henninges et al. (2012) \\
\hline Mauerstetten & $\begin{array}{l}\text { Limestone, } \\
\text { et al. (2012a) }\end{array}$ & Unknown & Unknown & 130, Schrage et al. (2012a) \\
\hline Falkenberg & Granite, MIT (2006d) & Unknown & Unknown & $\begin{array}{l}\text { 13.5, Kappelmeyer and } \\
\text { Jung (1987) }\end{array}$ \\
\hline Bad Urach & Gneiss, Tenzer et al. (2000) & Unknown & $\begin{array}{l}\mathrm{T} \text { (rock matrix) } 10^{-7} \text { to } 10^{-6} \text {, } \mathrm{T} \text { (frac- } \\
\text { tures) } 10^{-4} \text { to } 10^{-3} \text { at } 3320-3488 \mathrm{~m} \text {, Schanz } \\
\text { et al. }(2003 \text { ) }\end{array}$ & $\begin{array}{l}172 \text { at } 4445 \mathrm{~m} \text {, Tenzer }(2001) ; 112 \\
\text { at } 3200 \mathrm{~m} \text {, iTG }(2010)\end{array}$ \\
\hline Basel & $\begin{array}{l}\text { Granite, Ladner and } \\
\text { Häring (2009) }\end{array}$ & Unknown & $\begin{array}{l}\mathrm{K}=1 \times 10^{-17} \text { estimated, Ladner and } \\
\text { Häring (2009) }\end{array}$ & 174, Ladner and Häring (2009) \\
\hline Fjällbacka & Granite, Portier et al. (2007) & Unknown & $\begin{array}{l}\mathrm{K}=10^{-18} \text { to } 10^{-17} \text {, Jupe et al. (1992) } \\
\mathrm{T}=10^{-8} \text { to } 10^{-7} \text {, Wallroth et al. (1999) }\end{array}$ & 16, Wallroth et al. (1999) \\
\hline Rosemanowes & Granite, MIT (2006e) & Unknown & $\mathrm{K}^{i}=10^{-18}$ to $10^{-17}$, Parker $(1999)$ & 79-100, MIT (2006e) \\
\hline Eden & Granite, Baria et al. (2013) & 0.15 estimated, Atkins (2013) & $\mathrm{K}=9.9 \times 10^{-16}$ estimated, Atkins (2013) & 180 estimated, Baria et al. (2013) \\
\hline United Downs & Granite, Atkins (2013) & 0.15 estimated, Atkins (2013) & $\mathrm{K}=9.9 \times 10^{-16}$ estimated, Atkins (2013) & 180-200 estimated, Atkins (2013) \\
\hline Litoměřice & $\begin{array}{l}\text { Sedimentary and granite, } \\
\text { Stibitz et al. (2011) }\end{array}$ & Unknown & Unknown & $\begin{array}{l}\text { 63.5, Stibitz et al. (2011); } 178 \text { to } \\
207.5 \text { estimated at } 5 \mathrm{~km} \text {, Stibitz } \\
\text { et al. (2011) }\end{array}$ \\
\hline Ferencszállás & $\begin{array}{l}\text { Metamorphic schist and } \\
\text { partly granitoid, Sverrisson } \\
\text { et al. (2013) }\end{array}$ & Unknown & Unknown & $\begin{array}{l}170 \text { estimated, Sverrisson } \\
\text { et al. (2013) }\end{array}$ \\
\hline Newberry & $\begin{array}{l}\text { Volcanic rocks, Fitter- } \\
\text { mann (1988) }\end{array}$ & 0.01 to 0.20 , Sonnenthal et al. (2012) & $\begin{array}{l}\mathrm{K}=1.0 \times 10^{-18} \text { to } 1.5 \times 10^{-12} \text {, Sonnen- } \\
\text { thal et al. }(2012)\end{array}$ & 315, Cladouhos et al. 2012) \\
\hline Northwest Geysers & $\begin{array}{lr}\begin{array}{l}\text { Metasedimentary } \\
\text { (greywacke), }\end{array} & \text { rocks } \\
\text { et al. (1995) } & \end{array}$ & 0.01, Rutqvist et al. (2013) & $\mathrm{K}=2 \times 10^{-14}$, Rutqvist et al. (2013) & about 400, Garcia et al. (2012) \\
\hline Fenton Hill & $\begin{array}{l}\text { Crystalline } \\
\text { Brown }(2009)\end{array}$ & Unknown & Unknown & 180 to 327, MIT (2006f) \\
\hline Paralana & $\begin{array}{l}\text { Metasediments, granite, Pe- } \\
\text { tratherm (2014) }\end{array}$ & Unknown & Unknown & 190, Reid and Messeiller (2013) \\
\hline Cooper Basin & Granite, Majer et al. (2007) & Unknown & Unknown & 243 to 264 , Bendall et al. (2014) \\
\hline Olympic Dam & Granite, Lovelock (2011) & Unknown & Unknown & $\begin{array}{l}85.3 \text { at } 1934.2 \mathrm{~m}, \quad \text { Bendall } \\
\text { et al. (2014) } 190 \text { estimated at } \\
\text { target depth, Lovelock (2011) }\end{array}$ \\
\hline Parachilna & $\begin{array}{l}\text { Granite, Geoscience Aus- } \\
\text { tralia and ABARE (2010) }\end{array}$ & Unknown & Unknown & $\begin{array}{l}98.4 \text { at } 1807 \mathrm{~m}, 240 \text { estimated at } \\
4500 \mathrm{~m} \text {, Torrens Energy (2014) }\end{array}$ \\
\hline Frome & $\begin{array}{l}\text { Granite, Geoscience Aus- } \\
\text { tralia and ABARE (2010) }\end{array}$ & Unknown & Unknown & $\begin{array}{l}93.5 \text { at } 1761 \mathrm{~m}, 200 \text { estimated at } \\
4080 \mathrm{~m}, \text { Geoscience Australia and } \\
\text { ABARE (2010) }\end{array}$ \\
\hline Pohang & $\begin{array}{l}\text { Paleozoic granodiorite, Lee } \\
\text { et al. (2011) }\end{array}$ & Unknown & Unknown & 180 estimated, Lee et al. (2011) \\
\hline Hijiori & Granodiorite, Sasaki (1998) & 0.01, Sasaki (1998) & $\begin{array}{l}\mathrm{K} \text { (Rock matrix) } 10^{-19} \text { to } 10^{-21} \text {, } \\
\text { Sasaki (1998) }\end{array}$ & 190, DiPippo (2012) \\
\hline Ogachi & $\begin{array}{l}\text { Granodiorite, } \\
\text { et al. (2010) }\end{array}$ & Unknown & $\begin{array}{l}\mathrm{K}=0.8 \times 10^{-15} \text { to } 0.2 \times 10^{-13} \text {, Kaieda } \\
\text { et al. }(2005)\end{array}$ & 228, Kaieda et al. (2005) \\
\hline
\end{tabular}

a not clear whether Soultz project is petrothermal or HSA; ${ }^{i}$ permeability calculated from Darcy into $\mathrm{m}^{2}$ under assumption that water temperature is only $10{ }^{\circ} \mathrm{C}$ and fresh water; BHT - bottomhole temperature.

ences, the tables refer generically to hydraulic stimulation, which could mean either one of the hydraulic stimulation techniques, such as hydraulic fracturing, hydraulic shearing or a combination of both. Seismic events are given in Richter scale magnitudes. The type of power plant is commonly only available for those projects which are ongoing. All projects employ only binary power plants, such as organic rankine cycles (ORCs) or Kalina cycles. In the event of the information being available, it was possible to differentiate which type of binary power plant was used for each project. Installed elec- trical and thermal capacities could only be provided for the ongoing projects.

In what follows, specific projects have been highlighted which presented ambiguity in their classification.

\subsection{Petrothermal systems}

The European HDR project Soultz-sous-Forêts in France was categorized as a PS, although there has been much debate among experts as to whether this system should be cate- 


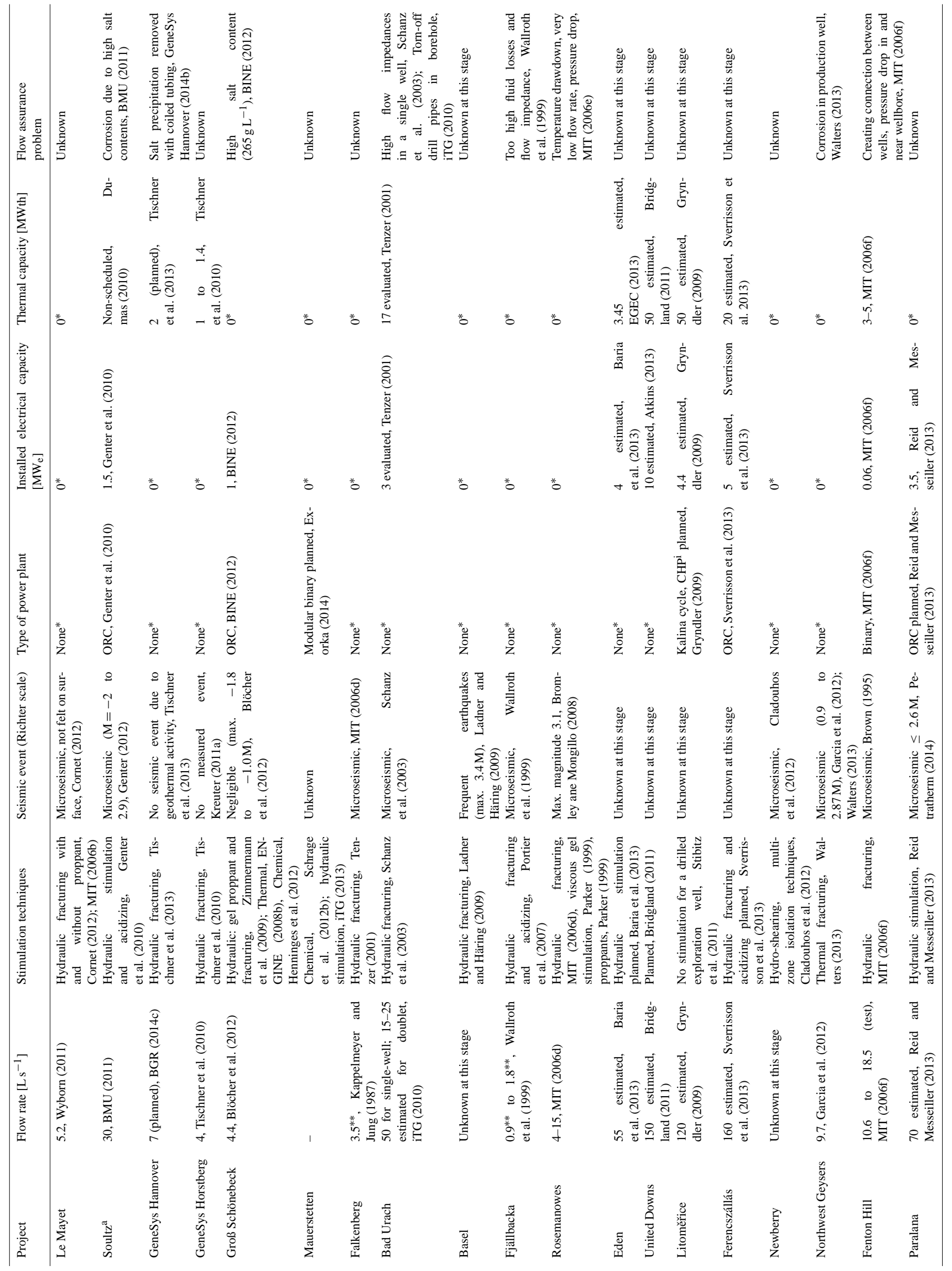




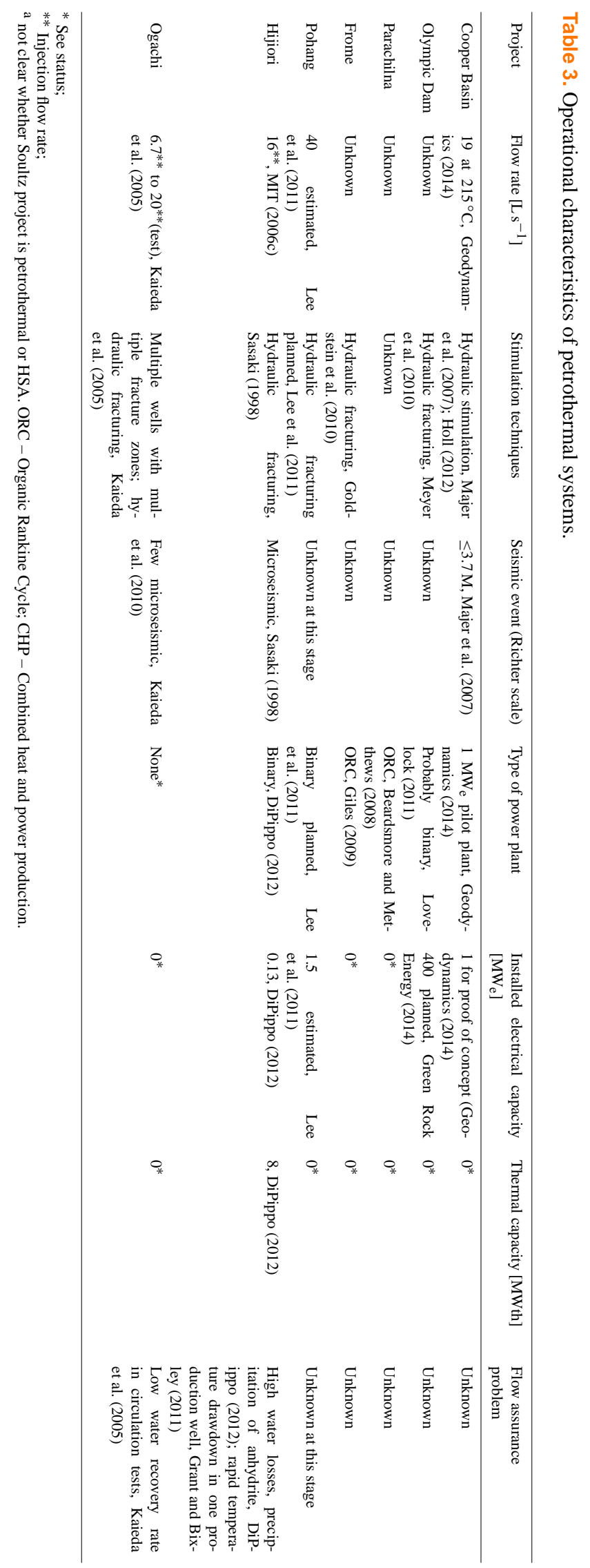




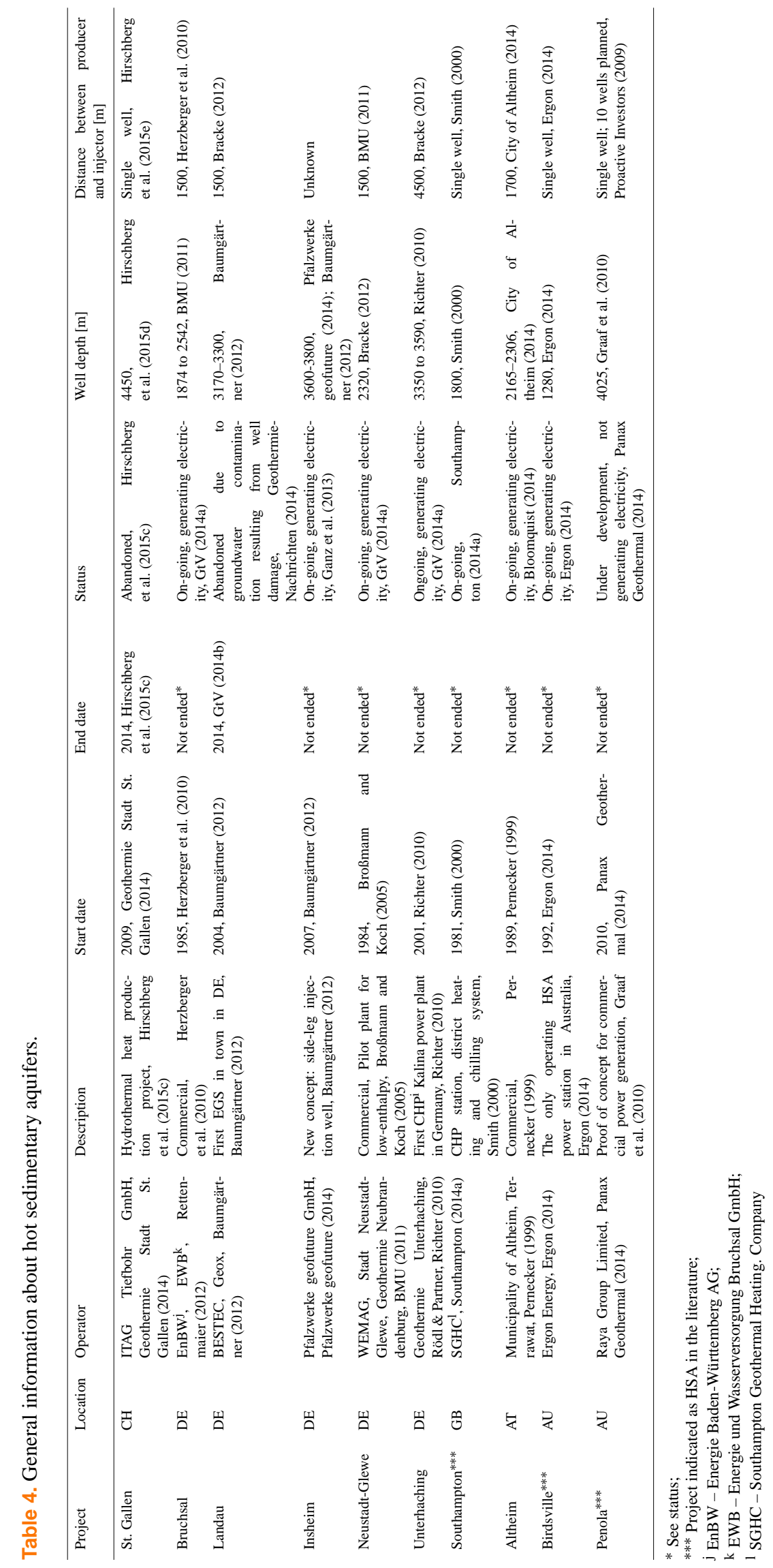


gorized as HDR, HFR or HSA (IGA R\&R, 2013). This discussion has probably arisen because two different reservoirs are connected to the project: the upper reservoir being in a fractured granite formation with higher permeabilities $\left(3 \times 10^{-14} \mathrm{~m}^{2}\right)$ and the lower reservoir in a fresh granite formation with much poorer permeabilities $\left(1 \times 10^{-17} \mathrm{~m}^{2}\right)$ (Kohl et al., 2000). Although Soultz was initially planned as an HDR project and therefore created in crystalline basement rocks, it was found that the reservoir contains permeable structures with substantial volumes of natural brine. Hence, it differs from the classic definition of HDR and the geothermal anomaly is mainly controlled by natural fluid flow (Genter et al., 2010). However, the low hydraulic connection of the fracture system required a permeability enhancement using hydraulic stimulation. Following the definition in Sect. 2, this would indicate that Soultz is a PS as hydraulic stimulation was required to enhance the productivity index.

Some explanation is necessary also for the Northwest Geysers project. According to Walters (2013), this is an EGS demonstration project, launched in 2009 with the main goal of enhancing the permeability of hot, low-permeable rocks by means of thermal fracturing and creating an EGS doublet capable of producing $5 \mathrm{MW}$. Garcia et al. (2012) refer to the high temperature reservoir (HTR) of this EGS demonstration area as non-hydrothermal HDR due to conductive temperature gradients and the project not being part of the pre-existing HS. However, the same source mentions presence of steam entries in the HTR in previously abandoned wells after re-opening and deepening.

\subsection{Hot sedimentary aquifers}

The HSA database consists of 10 projects, whereof only 3 projects (Southampton, Birdsville, and Penola) were actually indicated as HSA in the literature. Since the term HSA was only invented recently and there is no international standard for the categorization of such a geothermal system, it has to be assumed that not all projects which are HSA are also indicated as such in the literature. Therefore, based on the geological setting, additional hydrothermal projects were added to the tables, where it can be assumed that they are HSA projects.

One could argue about the classification of the St. Gallen project in Switzerland. The project's aim was to use the naturally fractured Malm formation in a depth of 4 to $4.5 \mathrm{~km}$ for an HS. However, during the preparations for the production test, an unexpected high gas inlet in the well required interventions to secure the well, which in turn resulted in induced seismic activity. Therefore, the project was put on hold in order to evaluate the gathered data from the production test and to readjust further project steps (Geothermie Stadt St. Gallen, 2014). The encountered dissolved natural gas in the well indicates that St. Gallen might actually be a geo-pressured system. However, it is likely that the gas was coming from deep-seated, highly faulted permo- carboniferous formations, which were penetrated by deep drilling. Hirschberg et al. (2015a), who do not differentiate between HS and HSA, classify St. Gallen as an HS. The analysed data with low flow rates of only 6 to $12 \mathrm{~L} \mathrm{~s}^{-1}$, the existing gas inlet in the well, the increased risk of induced seismicity, and limited financial funds, eventually resulted in the abandonment of the project in May 2014 (Hirschberg et al., 2015c).

\section{Results and discussion}

\subsection{Petrothermal Systems}

For almost all PSs, hydraulic fracturing was applied (with the exception of Northwest Geysers, where thermal fracturing was conducted instead). For four projects, stimulation was either not yet performed or no information about it could be found in the public domain. For the projects Eden and United Downs, it was only stated that stimulation will be applied in the future. In the cases of Mauerstetten, Soultz-sous-Forêts, and Fjällbacka, not only was hydraulic fracturing carried out, but chemical stimulation of the near-wellbore region was also performed. Groß Schönebeck was the only project where all three stimulation techniques (hydraulic, chemical and thermal) were implemented.

The well depths of PSs vary widely within a range of 70 to $5000 \mathrm{~m}$. However, most projects are deeper than $1800 \mathrm{~m}$, with exception of the three shallow HDR systems Le Mayet, Falkenberg, and Fjällbacka, which were never operational, but were only implemented for research and demonstration purposes.

The temperature range of most of the PSs is 130 to $400^{\circ} \mathrm{C}$, excluding the three abovementioned shallow systems and Rosemanowes, which have a lower temperature range of 79 to $100^{\circ} \mathrm{C}$.

Rock types are usually crystalline and volcanic, with rocks such as granite and granodiorite with exception of GeneSys Hannover (Bunter sandstone), GeneSys Horstberg (sedimentary), Mauerstetten (limestone), and Northwest Geysers (metasedimentary rocks).

For those nine projects where porosity values were available in the public domain, the porosity shows a very wide range from 0.0025 to 0.25 , depending on the type of porosity. For example, the former value represents the connected porosity, such as the fresh Soultz granite, and the highest value is related to the altered rock in Soultz. However, most projects have porosities in the range of 0.01 to 0.20 .

Permeability values were available for 13 petrothermal projects: the lowest value was found for Hijiori in Japan with $10^{-21} \mathrm{~m}^{2}$ and the highest one for Newberry with $1.5 \times 10^{-12} \mathrm{~m}^{2}$. Hence, the permeability range is 9 orders of magnitude. In addition, the permeability changed significantly for one project: in the case of Newberry, permeability values from $10^{-18}$ to $1.5 \times 10^{-12}$ were found in the literature. The latter value is high enough for HSs, but considering 
Table 5. Petrophysical properties of hot sedimentary aquifers.

\begin{tabular}{|c|c|c|c|c|}
\hline Project & Rock type & Porosity & $\begin{array}{l}\text { Permeability } \\
{\left[\mathrm{m}^{2}\right] / \text { Transmissivity }(\mathrm{T})\left[\mathrm{m}^{2} \mathrm{~s}^{-1}\right]}\end{array}$ & $\begin{array}{l}\text { BHT/reservoir } \\
{\left[{ }^{\circ} \mathrm{C}\right]}\end{array}$ \\
\hline St. Gallen & $\begin{array}{l}\text { Malm, shell lime- } \\
\text { stone, } \quad \text { Hirschberg } \\
\text { et al. }(2015 \mathrm{e})\end{array}$ & Unknown & Unknown & $\begin{array}{l}>145, \quad \text { Brunner } \quad \text { and } \\
\text { Huwiler }(2014)\end{array}$ \\
\hline Bruchsal & $\begin{array}{l}\text { Bunter sand- } \\
\text { stone, Herzberger } \\
\text { et al. }(2010)\end{array}$ & Unknown & $\begin{array}{l}\mathrm{T}=8.1 \times 10^{-5}-4.0 \times 10^{-3}, \\
\text { Herzberger et al. }(2010)\end{array}$ & 120, Herzberger et al. (2010) \\
\hline Landau & $\begin{array}{lr}\begin{array}{l}\text { Sedimentary } \\
\text { igneous }\end{array} & \text { and } \\
\text { Atkins (2013) } & \text { rocks, }\end{array}$ & Unknown & Unknown & 159, Baumgärtner (2012) \\
\hline Insheim & $\begin{array}{l}\text { Keuper, perm, bunter } \\
\text { sandstone, granite, } \\
\text { Baumgärtner (2012) }\end{array}$ & Unknown & Unknown & 160, Baumgärtner (2012) \\
\hline Neustadt-Glewe & $\begin{array}{l}\text { Sandstone, } \\
\text { BMU (2011) }\end{array}$ & $\begin{array}{l}\text { Well logging } \sim 0.25 \text {, lab } \\
\sim 0.22 \text {, BMU }(2011)\end{array}$ & $\begin{array}{l}\text { Well logging } \mathrm{K}^{\mathrm{i}} \sim 1.4 \times 10^{-12}, \\
\text { laboratory measurements } \\
\sim 0.5 \times 10^{-12}, \mathrm{BMU}(2011)\end{array}$ & 99, Bracke (2012) \\
\hline Unterhaching & $\begin{array}{l}\text { Limestone, } \\
\text { mas }(2010)\end{array}$ & Unknown & Unknown & 122 and 133, Richter (2010) \\
\hline Southampton*** & $\begin{array}{l}\text { Triassic Sher- } \\
\text { wood Sandstone, } \\
\text { Smith (2000) }\end{array}$ & Unknown & $\begin{array}{lcr}\mathrm{K}^{\mathrm{m}}=2.63 & \text { to } & 5.26 \times 10^{-13}, \\
\text { Atkins } & (2013), & \text { Southamp- } \\
\text { ton }(2014 \mathrm{c}) & \end{array}$ & 76, Smith (2000) \\
\hline Altheim & $\begin{array}{l}\text { Limestone, City of Al- } \\
\text { theim (2014) }\end{array}$ & $\begin{array}{l}0.08-0.28, \\
\text { GINE (2008b) }\end{array}$ & $\begin{array}{l}\mathrm{T}=1 \times 10^{-4}-1 \times 10^{-2}, \\
\text { GINE }(2008 \mathrm{~b})\end{array}$ & 106, Bloomquist (2014) \\
\hline Birdsville*** & Unknown & Unknown & Unknown & 98, Ergon (2014) \\
\hline Penola*** & $\begin{array}{l}\text { Sandstone, Panax } \\
\text { Geothermal (2014) }\end{array}$ & $\begin{array}{l}0.14, \text { Hot Rock Lim- } \\
\text { ited (2010) }\end{array}$ & $\begin{array}{l}\mathrm{K}^{\mathrm{m}}=5.96 \times 10^{-15}-1.2 \times 10^{-14}, \\
\text { Graaf et al. }(2010)\end{array}$ & 171.4, Graaf et al. (2010) \\
\hline
\end{tabular}

${ }^{\mathrm{i}}$ permeability calculated from Darcy into $\mathrm{m}^{2}$ under assumption that water temperature is only $10^{\circ} \mathrm{C}$ and fresh water;

$\mathrm{m}$ Permeability calculated from transmissivity in case of known reservoir thickness;

*** Project indicated as HSA in the literature: Southampton, Atkins (2013); Penola, Graaf et al. (2010); Birdsville, RBS Morgans (2009).

the whole permeability range together with other factors such as water not being naturally available, the Newberry project should still be categorized as a PS.

The production flow rate ranges from 4 to $50 \mathrm{~L} \mathrm{~s}^{-1}$. However, flow rates as high as $120 \mathrm{~L} \mathrm{~s}^{-1}$ are expected in Litomerrice in the Czech Republic and $150 \mathrm{~L} \mathrm{~s}^{-1}$ in the case of United Downs in Great Britain.

The most common flow assurance problems were high salt content, high fluid losses, pressure drop, and corrosion.

\subsection{Hot sedimentary aquifers}

For only 5 of the 10 HSA projects, information could be found that stimulation was applied to increase the permeability. For three projects hydraulic fracturing was applied; for two projects both hydraulic and chemical stimulation was conducted. Unterhaching in Germany was the only project where chemical stimulation alone was applied. No information as to whether stimulation techniques were conducted or not could be found for the remaining three projects, which are indicated as HSA in the literature.

The well depth ranges from 1280 to $4450 \mathrm{~m}$ for the HSA projects. The encountered rock types are mostly sandstone and limestone and other sedimentary rocks; this is, for instance, the case for Bruchsal. For Birdsville, no information about a rock type could be found. In the cases of Landau and Insheim, igneous rocks were found in addition to sandstone.
Porosity values were found for 3 of the 10 projects only, ranging from 0.08 to 0.28 . For three projects, permeability values were given in the literature with a range of $5.96 \times 10^{-15}$ to $1.4 \times 10^{-12} \mathrm{~m}^{2}$. The lowest value was found to be for the Penola project in Australia, which was indicated as HSA in the literature.

Production flow rates of 6 to $150 \mathrm{Ls}^{-1}$ were found, whereof the highest flow rate was encountered in Unterhaching and the lowest one in St. Gallen $\left(6 \mathrm{~L} \mathrm{~s}^{-1}\right)$. As mentioned before, one of the reasons for abandonment of the latter project was the overly low flow rates. Excluding St. Gallen, the lowest flow rate is $27 \mathrm{~L} \mathrm{~s}^{-1}$.

The most common flow assurance problems were high salt content followed by overly low flow rate and high gas concentration.

\section{Numerical criteria for classification of deep geothermal potential}

Table 7 shows the most typical ranges for different parameters such as permeability, temperature, well depth, rock type, flow rate, stimulation technique, and porosity for both PSs and HSA systems. These values are based on the authors' database and are not meant to be exclusive. The values are quite similar to each other and sometimes the parameter ranges are even overlapping, suggesting that these quantita- 


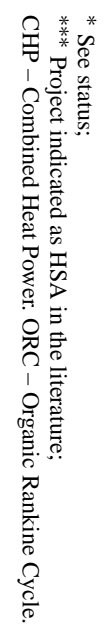

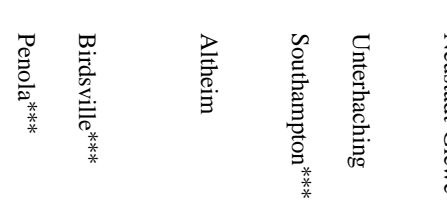

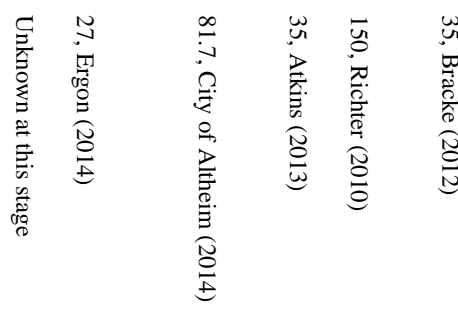

(2)

I

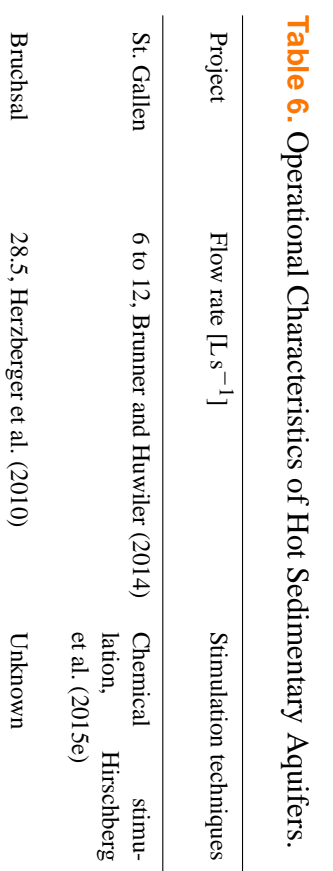

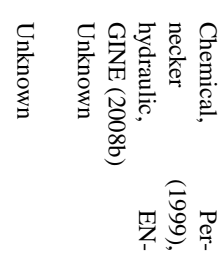

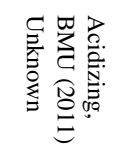

$\stackrel{\substack{5 \\ \hline}}{\stackrel{5}{5}}$

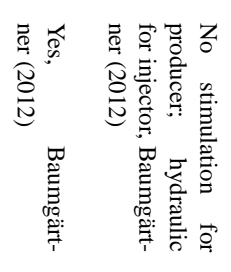

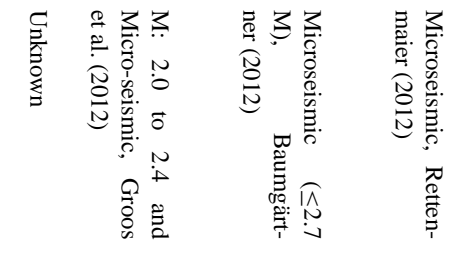

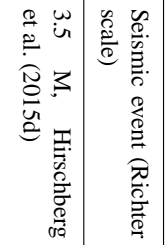

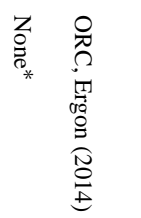

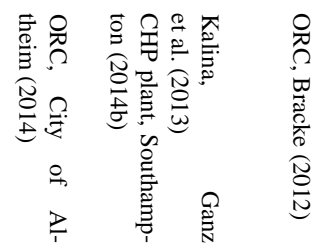

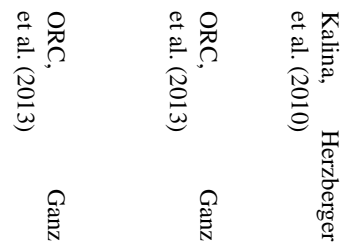

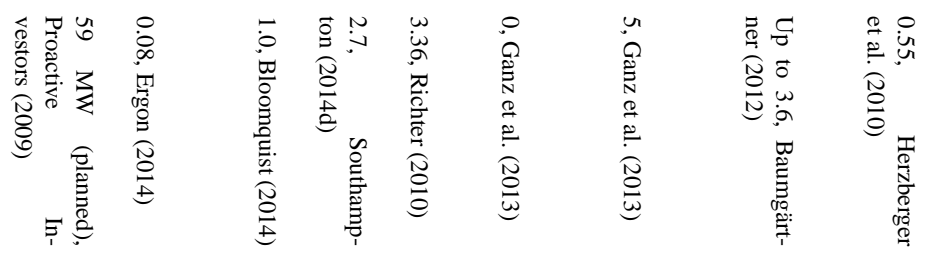

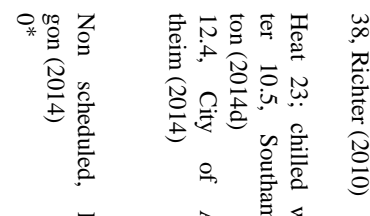

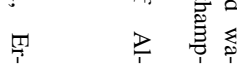

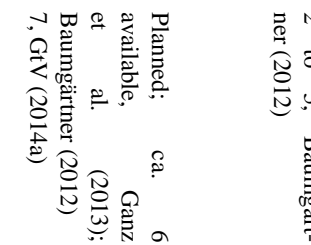

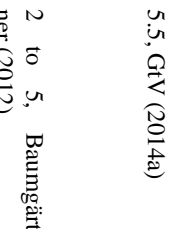

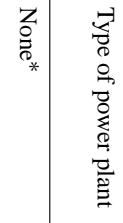

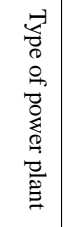

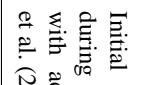

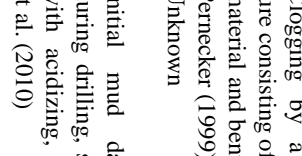

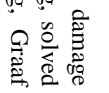

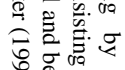

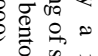

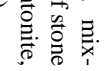

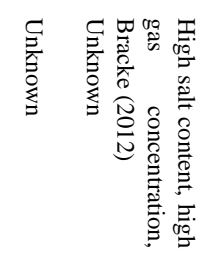

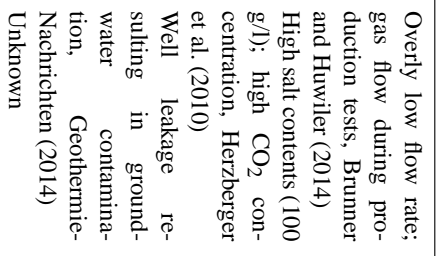

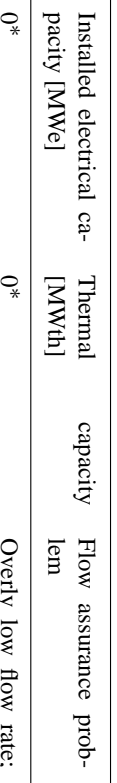


Table 7. Typical parameter ranges for petrothermal systems and hot sedimentary aquifers.

\begin{tabular}{lll}
\hline Parameter & Petrothermal & Hot sedimentary aquifer \\
\hline Permeability & $10^{-19}-10^{-14} \mathrm{~m}^{2}$ & $10^{-15}-10^{-12} \mathrm{~m}^{2}$ \\
Temperature & $130-400^{\circ} \mathrm{C}$ & $76-171.4^{\circ} \mathrm{C}$ \\
Well depth & $1800-5000 \mathrm{~m}$ & $1280-4450 \mathrm{~m}$ \\
Rock type & Igneous & Sedimentary \\
Stimulation & Hydraulic & Hydraulic and/or chemical \\
Porosity & $0.01-0.25$ & $0.08-0.28$ \\
Flow Rate & $4-50 \mathrm{~L} \mathrm{~s}^{-1}$ & $27-150 \mathrm{~L} \mathrm{~s}^{-1}$ \\
\hline
\end{tabular}

tive parameters may not be used to differentiate PSs from HSA systems.

Additional important parameters such as productivity index and the productivity enhancement factor resulting from stimulation were unavailable in the public domain for most of the projects.

\section{Conclusions}

Over the past 40 years, more and more geothermal system classifications such as hot dry rock, enhanced or engineered geothermal systems, hot wet rock, hot fractured rock, and HSA systems have been defined in order to better characterise geothermal projects. However, some of these definitions are deceptive, such as that for deep heat mining, which suggests that the geothermal heat is mined and therefore not available anymore after the geothermal production. Other definitions (such as those for EGS) are not specific, as they provide only the information that the geothermal system was somehow enhanced by some technical measure such as water supply, stimulation of the reservoir etc.

This study recommends re-introducing three known definitions such as petrothermal, hydrothermal, as well as HSA, and abandoning the ambiguous terminology such as EGS. This threefold classification provides more information compared to the defined EGS, which is unfortunately quite common nowadays.

The definition of petrothermal already includes the information that not enough water is contained in the subsurface and thus water has to be supplied and re-injected after geothermal production. Hence, more than one well is required for the project. However, this is not a distinctive criterion, as most of HSs and HSA systems consist of two wells, with exception of Birdsville and Southampton. In addition, the permeability is too low for the production well and therefore hydraulic fracturing has to be applied as stimulation in order to create an artificial reservoir. PSs, which sit in the first-proposed category, indicate a conduction-dominated heat source. Based on the authors' own database, typical permeability ranges are in the order of $10^{-19}$ to $10^{-14} \mathrm{~m}^{2}$, the most common formation type is igneous such as granite, well depth is typically more than $1800 \mathrm{~m}$, and hydraulic stimulation has to be applied in order to create an artificial reservoir. The temperature of investigated petrothermal projects varies significantly with typical ranges between 130 and $400^{\circ} \mathrm{C}$.

On the other hand, the definition of hydrothermal informs us that a geothermal reservoir, with high enough permeability and sufficient water supply, is already available and that (usually) no stimulation needs to be applied, but the project might be improved if formation damage is reduced via more careful drilling or the near-wellbore region is stimulated. HSs, which occupy the second proposed category, can be managed with only one well if the water is additionally used for other purposes such as balneology. However, for sustainability and to maintain high pressure in the reservoir, it might be required to re-inject the produced water, which would mean that a second well would be necessary. Re-injection might also be necessary in case of the water being saline to avoid environmental risks. HSs indicate a convection-dominated or an advection-dominated heat source.

The third proposed category is HSA systems. These systems are similar to common and conventional HSs with the difference being that the heat supply is conductiondominated and the heat source is similar to PSs, such as high heat producing granites seen in the Australian HSA systems. The analysis of HSA projects resulted in the following typical parameter ranges: permeability from $10^{-15}$ to $10^{-12} \mathrm{~m}^{2}$, temperature from 76 to $171.4^{\circ} \mathrm{C}$, well depth between 1280 and $4450 \mathrm{~m}$; reservoir rock types are typically sedimentary, such as sandstone and limestone.

Acknowledgements. The authors would like to acknowledge the financial support of the Open Access Publishing Fund at Clausthal University of Technology to publish this paper.

Edited by: G. Beardsmore

\section{References}

AGRCC: Australian Geothermal Reporting Code Committee: Geothermal lexicon for resources and reserves definition and reporting, 2nd edn. Australian Geothermal Reporting Code Committee, Adelaide, p. 67, 2010.

Atkins Ltd: Deep Geothermal Review Study, Version 5.0, 21 October 2013.

Baria, R., Bennett, T., Macpherson-Grant, G., Baumgaertner, J., and Jupe, A.: Cornish Rocks - Hotting Up? European Geothermal Congress (EGC) 2013, Pisa, Italy, 3-7 June 2013.

Barnet, P.: Large scale hot sedimentary aquifer (HSA) geothermal projects, Presentation to Victoria Energy Conference, Melbourne, 27 August 2009.

Baumgärtner, J.: Insheim and Landau - recent experiences with EGS technology in the Upper Rhine Graben, oral presentation presented at ICEGS 2012, Freiburg, 25 May 2012. 
Beardsmore, G. and Matthews, C.: Parachilna Geothermal Play, Statement of Inferred Geothermal Resources, Torrens Energy Limited, 15 August 2008.

Bendall, B., Hogarth, R., Holl, H., McMahon, A., Larking A., and Reid, P.: Australian Experiences in EGS Permeability Enhancement - A Review of 3 Case Studies. PROCEEDINGS, ThirtyNinth Workshop on Geothermal Reservoir Engineering, SGPTR-202, Stanford University, Stanford, California, 24-26 February 2014.

Bertani, R.: Geothermal power generation in the world 2005-2010 update report, Geothermics, 41, 1-29, 2012.

BGR (2014a): GeneSys Horstberg, http://www.genesys-hannover. de/Genesys/EN/Horstberg/horstberg_node_en.html, last access: 2 June 2014.

BGR (2014b): Milestones of the Genesys project, http: //www.bgr.bund.de/Genesys/EN/Meilensteine/meilensteine_ inhalt_en.html, last access: 2 June 2014.

BGR (2014c): GeneSys, http://www.genesys-hannover.de/ Genesys/DE/Home/genesys_node.html, last access: 10 June 2014

BINE (2012): Korrosion in geothermischen Anlagen. http://www.bine.info/service/bestellen/download-print/ publikation/korrosion-in-geothermischen-anlagen/ korrosion-und-materialqualifizierung/, last access: 2 June 2014.

Blöcher, G., Zimmermann, G., Moeck, I., and Huenges, E.: GroßSchönebeck (D) - the development of the learning curve: experience from the projects of recent years. Oral presentation presented at ICEGS 2012, Freiburg, 25 May 2012.

Bloomquist, R.: Integrating small power plants into agricultural projects, pangea.stanford.edu/ERE/pdf/IGAstandard/EGC/ szeged/I-8-01.pdf, last access: 3 June 2014.

BMU: Tiefe Geothermie - Nutzungsmöglichkeiten in Deutschland, Beltz Bad Langensalza GmbH, BT Weimar, Bundesministerium für Umwelt, Naturschutz und Reaktorsicherheit, Referat Öffentlichkeitsarbeit, Berlin, 2011.

Bracke, R.: Geothermal energy - low enthalpy technologies. Oral presentation presented at Congreso Nacional de Energia 2012, CICR, San Jose/Costa Rica, 15-16 February 2012.

Breede, K., Dzebisashvili, K., Liu, X., and Falcone, G.: A systematic review of enhanced (or engineered) geothermal systems: past, present and future, Geotherm Energ., 1, doi:10.1186/21959706-1-4, 2013.

Bridgland, D.: United Downs Deep Geothermal Project, Progress Summary of Geothermal Engineering Ltd., 17 November 2011.

Bromley, C. J. and Mongillo, M. A.: Geothermal energy from fractured reservoirs - dealing with induced seismicity. In: IEA OPEN Energy Technology Bulletin, Issue No. 48, IEA, http://www.iea. org/impagr/cip/pdf/Issue48Geothermal.pdf (last access: 02 June 2014), 2008.

Broßmann, E. and Koch, M.: First Experiences with the Geothermal Power Plant in Neustadt-Glewe (Germany) - Proceedings World Geothermal Congress 2005, Antalya, Turkey, 24-29 April 2005.

Brown, D.: The US Hot Dry Rock program - 20 years of experience in reservoir testing. Paper presented at world geothermal congress 1995, Firenze, 18-31 May 1995.

Brown, D. (2009): Hot Dry Rock Geothermal Energy: important lessons from Fenton Hill. Paper presented at thirty-fourth work- shop on geothermal reservoir engineering, Stanford University, Stanford, 9-11 Feb 2009.

Brunner, F. and Huwiler, M.: Geothermie-Projekt St.Gallen, Ergebnis Produktionstests, weitere Schritte,Medienmitteilung der Stadt St. Gallen, retrieved from: http://www.geothermie. stadt.sg.ch/fileadmin/downloads/medienmitteilungen/140213_ MK_Geothermie.pdf (ast access: 17 March 2015), 13 February 2014.

Canaris, J. (2009): Company Overview. Torrens Energy Limited. November 2009

City of Altheim (2014): City of Altheim - Geothermal energy supply. http://engine.brgm.fr/web-offlines/conference-Electricity_ generation_from_Enhanced_Geothermal_Systems_-_ Strasbourg,_France,_Workshop5/other_contributions/ 27-slides-0-2_Altheim_pdf.pdf last access: 11 December 2014.

Cladouhos, T. T., Osborn, W. L., Petty, S., Bour, D., Iovenitti, J., Callahan, O., Nordin, Y., Perry, D., and Stern, P. L.: Newberry volcano EGS demonstration - phase I results. In: Proceedings of thirty-seventh workshop on geothermal reservoir engineering, Stanford University, Stanford, 30 January-1 February 2012.

cleanenergyaus: Geothermal Energy Sources, http: //cleanenergyaus.com.au/technology.htm, last access: 18 June 2014.

Cornet, F. H.: Results from Le Mayet De Montagne Project, Geothermics, 16, 355-374, 1987.

Cornet, F. H.: The learning curve: the Le Mayet de Montagne experiment (1978-1987), Oral presentation presented at ICEGS 2012, Freiburg, 25 May 2012.

Cuenot, N.: Overview of Microseismic activity observed at the Soultz-sous-Forêts EGS power plant under stimulation and circulation conditions, 75th EAGE conference and exhibition, Workshop 16, Microseismicity - What now? What next?, London, UK, 13-16 June 2013.

Cummings, R. G. and Morris, G. E.: Economic modelling of electricity production from Hot Dry Rock geothermal reservoirs: methodology and analysis. EA-630, Research Project 1017 LASL (LA-7888-HDR). OSTI Information Bridge., http://www.osti.gov/bridge/servlets/purl/5716131-wg4gUV/ native/5716131.pdf (last access: 31 May 2013), 1979.

DiPippo, R.: Geothermal power plants, 3rd edn, Elsevier, New York, 451-456, 2012.

Duchane, D.: The history of HDR research and development, in: Draft proceedings of the 4th international HDR forum, Strasbourg, 28-30 September 1998.

Dumas, P.: NER300: what for geothermal? Oral presentation held at second EGEC TP geoelec meeting, Brussels, 24 March 2010.

EGEC: EGEC Market report 2013/2014, third edition, December 2013.

ENGINE (): ENGINE - geothermal lighthouse projects in Europe, last update: April 2008, http://engine.brgm.fr/mediapages/ lighthouseProjects/LH-Quest_EGS_4_GeneSys.pdf (last access: 27 May 2014), 2008a.

ENGINE: ENGINE coordination action. Best practice handbook for the development of unconventional geothermal resources with a focus on enhanced geothermal system, BRGM, Orleans, ISBN 978-2-7159-2482-6, 40-41, 2008b.

Ergon: Birdsville Organic Rankine Cycle Geothermal Power Station. https://www.ergon.com.au/_data/assets/pdf_file/0008/ 
4967/EGE0425-birdsville-geothermal-brochure-r3.pdf, last access: 13 May 2014.

Exorka: F\&E-Projekt Geothermie Allgäu 2.0., http://cif-ev.de/pdf/ block2/P1.pdf, last access: 28 May 2014.

Fittermann, D. V.: Overview of the structure and geothermal potential of Newberry Volcano, Oregon, J. Geophys. Res., 93, 1005910066, 1988.

Flores, M., Davies, D., Couples, G., and Palsson, B.: Stimulation of Geothermal Wells, Can We Afford It?, Proceedings World Geothermal Congress 2005, Antalya, Turkey, 24-29 April 2005.

Ganz, B., Schellschmidt, R., Schulz, R., and Sanner, B.: Geothermal Energy Use in Germany, European Geothermal Congress 2013 Pisa, Italy, 3-7 June, 2013.

Garcia, J., Walters, M., Beall, J., Hartline, C., Pingol, A., Pistone, S., and Wright, M.: Overview of the Northwest Geysers EGS Demonstration Project. In: Proceedings of the thirty-seventh workshop on geothermal reservoir engineering (ed) Proceedings of the thirty-seventh workshop on geothermal reservoir engineering. Stanford University, Stanford, 30 January-1 February 2012.

GeneSys Hannover: In-situ Experiments. http://www. genesys-hannover.de/Genesys/EN/Forschung/In-Situ/in-situ_ inhalt_en.html (last access: 28 April 2014), 2014a.

GeneSys Hannover: Aktuelles. http://www.genesys-hannover.de/ Genesys/DE/Aktuelles/aktuelles_node.html (last access: 28 May 2014), 2014b.

Genter, A.: Lessons learned from projects in the early stage of EGS development: Soultz-sous-Fôrets (F), oral presentation held at ICEGS 2012, Freiburg, 25 May 2012.

Genter, A., Guillou-Frottier, L., Feybesse, J.-L., Nicol, N., Dezayes, C., and Schwartz, S.: Typology of potential hot fractured rock resources in Europe, Geothermics, 32, 701-710, 2003.

Genter, A., Evans, K., Cuenot, N., Fritsch, D., and Sanjuan, B.: Contribution of the exploration of deep crystalline fractured reservoir of Soultz to the knowledge of enhanced geothermal systems (EGS), CR GEOSCI, 342, 502-516, 2010.

Geodynamics: Innamincka (EGS) Project, urlhttp://www.geodynamics.com.au/Our-Projects/InnaminckaDeeps.aspx, last access: 30 May 2014.

Geoscience Australia and ABARE: Australian Energy Resource Assessment, Canberra, Commonwealth of Australia, 215-216, 2010.

Geothermal Resources: Frome Project (North Eastern SA), http:// www.geothermal-resources.com.au/project_frome.html, last access: 26 May 2014.

Geothermie-Nachrichten: Landau: Grundwasser am GeothermieKraftwerk verunreinigt, http://www.geothermie-nachrichten. de/landau-grundwasser-am-geothermie-kraftwerk-verunreinigt, last access: 13 June 2014.

Geothermie Stadt St. Gallen: Das Geothermie-Projekt der Stadt St. Gallen, http://www.geothermie.stadt.sg.ch/projekt.html, last access: 28 May 2014.

Giardini, D.: Geothermal quake risks must be faced, Nature, 462, 848-849, 2009.

Giles, C.: Frome Project - Statement of Estimated Geothermal Resources, Media Release on 13th of July 2009 from Geothermal Resources Limited, retrieved from: http://www.geothermal-resources.com.au/pdf/Resource Statement_130709.pdf (last access: 17 March 2015), 2009.
Goldstein, B. A., Bendall, B., and Long, A.: Australian 2009 Annual Country Report for the International Energy Agency Geothermal Implementing Agreement, Appendix A: Company Status Updates for 2009, Australian Geothermal Energy group; retrieved from: http://www.geothermal.dmitre.sa.gov.au/_data/assets/pdf_ file/0018/156114/2009_Australian_Country_Rpt_Final_.pdf (last access: 16 March 2015) 13 August 2010.

Graaf, B., Reid, I., Palmer, R., Jenson, D., and Parker, K.: Salamander-1 - a geothermal well based on petroleum exploration results, edited by: Gurgenci, H. and Weber, R. D., Proceedings of the 2010 Australian Geothermal Energy Conference, Geoscience Australia, Record 2010/35, 2010.

Grant, M. A. and Bixley, P. F.: Geothermal Reservoir Engineering. 2nd edition, Elsevier Inc, 478-479, 2011.

Grassiani, M., Krieger, Z., and Legmann, H.: Advanced power plants for use with HDR/enhanced geothermal technology, Bulletin D'Hydrogéologie No. 17, 165-172, 1999.

Green Rock Energy: Olympic Dam (100\% owned), http://www. greenrock.com.au/assetsSAOlympicDam.php, last access: 25 May 2014.

Groos, J. C., Grund, M., and Ritter, J. R. R.: Automated detection of microseismic events in the Upper Rhine valley near the city of Landau/South Palatinate. Geophys. Res. Abstr., 14, EGU201210482, EGU General Assembly 2012.

Gryndler, P.: City of Litoměřice Geothermal Project http://www.eeportal.mk/gallery/files/Day_4_-_Geothermal_ and_solar_energy.pdf, 2009.

GtV (Bundesverband Geothermie): Liste der tiefen Geothermieprojekte in Deutschland, http://www.geothermie.de/wissenswelt/ geothermie/in-deutschland.html (last access: 3 June 2014), 2014a.

GtV (Bundesverband Geothermie) (): Zügige Ursachenforschung in Landau, 11 April 2014 - Tiefe Geothermie, http://www.geothermie.de/news-anzeigen/2014/04/11/ zugige-ursachenforschung-in-landau.html (last access 29 May 2014), 2014b.

GtV (Bundesverband Geothermie) (2014c): Petrothermale Geothermie, http://www.geothermie.de/wissenswelt/geothermie/ technologien/petrothermale-systeme.html (last access: 13 June 2014), 2014c.

GtV (Bundesverband Geothermie) (2014d): Hydrothermale Geothermie, http://www.geothermie.de/wissenswelt/geothermie/ technologien/hydrothermale-systeme.html (last access: 13 June 2014), 2014d.

Häring, M. O.: Geothermische Stromproduktion aus Enhanced Geothermal Systems (EGS) Stand der Technik, www.geothermal.ch/fileadmin/docs/downloads/egs061207.pdf (last access: 30 January 2013), 2007.

Henninges, J., Brandt, W., Erbas, K., Moeck, I., Saadat, A., Reinsch, T., and Zimmermann, G.: Downhole monitoring during hydraulic experiments at the in-situ geothermal lab Groß Schönebeck, in: Proceedings of the thirty-seventh workshop on geothermal reservoir engineering, Stanford University, SProceedings, ThirtySeventh Workshop on Geothermal Reservoir Engineering, SGPTR-194, Stanford University, Stanford, California, 30 January-1 February 2012.

Herzberger, P., Münch, W., Kölbel, T., Bruchmann, U., Schlagermann, P., Hötzl, H., Wolf, L., Rettenmaier, D., Steger, H., Zorn, 
R., Seibt, P., Möllmann, G.-U., Sauter, M., Ghergut, J., and Ptak, T.: The Geothermal Power Plant Bruchsal. Proceedings World Geothermal Congress 2010, Bali, Indonesia, 25-29 April 2010.

Hirschberg, S., Wiemer, S., and Burgherr, P. (eds.): Energy from the Earth - Deep Geothermal as a Resource for the Future? Vdf Hochschulverlag AG an der ETH Zürich, ISBN 978-3-72813655-8/, p. 32, doi:10.3218/3655-8, 2015a.

Hirschberg, S., Wiemer, S., and Burgherr, P. (eds.): Energy from the Earth - Deep Geothermal as a Resource for the Future? Vdf Hochschulverlag AG an der ETH Zürich, ISBN 978-3-72813655-8/, p. 274, doi:10.3218/3655-8, 2015b.

Hirschberg, S., Wiemer, S., and Burgherr, P. (eds.): Energy from the Earth - Deep Geothermal as a Resource for the Future? Vdf Hochschulverlag AG an der ETH Zürich, ISBN 978-3-72813655-8/, p. 19, doi:10.3218/3655-8, 2015c.

Hirschberg, S., Wiemer, S., and Burgherr, P. (eds.): Energy from the Earth - Deep Geothermal as a Resource for the Future? Vdf Hochschulverlag AG an der ETH Zürich, ISBN 978-3-72813655-8/, p. 130, doi:10.3218/3655-8, 2015d.

Hirschberg, S., Wiemer, S., and Burgherr, P. (eds.): Energy from the Earth - Deep Geothermal as a Resource for the Future? Vdf Hochschulverlag AG an der ETH Zürich, ISBN 978-3-72813655-8/, p. 278-282 doi:10.3218/3655-8, 2015e.

Holl, H.: Geodynamics Update: Innamincka Deeps EGS Project, oral presentation held at ICEGS 2012, Freiburg, 25 May 2012.

Hot Rock Limited (2010): Annual Report 2010.

Huddlestone-Holmes, C. R. and Hayward, J.: The potential of geothermal energy, http://www. garnautreview.org.au/update-2011/commissioned-work/

potential-of-geothermal-energy.pdf (last access: 17 June 2014), 2011.

Huddlestone-Holmes, C. R. and Russel, C.: AEMO $100 \%$ Renewable Energy Study: Geothermal Energy, CSIRO, Newcastle, Australia, p. 10, 2012.

Huenges, E.: Geothermal energy systems - exploration, development, and utilization. Wiley, Weinheim, p. 22, 2010a.

Huenges, E.: Geothermal energy systems - exploration, development, and utilization. Wiley, Weinheim, 27-30, $2010 \mathrm{~b}$.

Huenges, E.: Geothermal energy systems - exploration, development, and utilization. Wiley, Weinheim, 184-185, 2010c.

IGA R\&R: International Geothermal Association, Resources and Reserves adhoc-committee, internal committee discussion, November 2013.

iTG: HDR-Projekt in Bad Urach vor dem Aus. 15 December 2010. http://www.tiefegeothermie.de/news/ hdr-projekt-in-bad-urach-vor-dem-aus (last access: 30 May 2014), 2010.

iTG: Mauerstetten soll als Forschungsprojekt neu erschlossen werden., http://www.tiefegeothermie.de/news/ mauerstetten-soll-als-forschungsprojekt-neu-erschlossen-werden (last access: 2 June 2014), 2013.

Jung, R.: EGS - Goodbye or Back to the Future, Effective and Sustainable Hydraulic Fracturing, Dr. Rob Jeffrey (Ed.), ISBN: 978-953-51-1137-5, InTech, doi:10.5772/56458, available from: http://www.intechopen. com/books/effective-and-sustainable-hydraulic-fracturing/ egs-goodbye-or-back-to-the-future-95, 2013.

Jupe, A. J., Green, A. S. P., and Wallroth, T.: Induced microseismicity and reservoir growth at the Fjällbacka hot dry rocks project,
Sweden. Int J Rock Mechanics Mining Sci Geomechanics Abstracts 29, 343-354, 1992.

Kaieda, H., Ito, H., Kiho, K., Suzuki, K., Suenaga, H., and Shin, K.: Review of the Ogachi HDR project in Japan, in: Proceedings of the world geothermal congress 2005, Antalya, 24-29 April 2005.

Kaieda, H., Sasaki, S., and Wyborn, D.: Comparison of characteristics of micro-earthquakes observed during hydraulicstimulation operations in Ogachi, Hijiori and Cooper Basin HDR projects, in: Proceedings of the World Geothermal Congress 2010, Bali, 25-29 April 2010.

Kappelmeyer, O. and Jung, R.: HDR experiments at Falkenberg/Bavaria, Geothermics, 16, 375-392, 1987.

Kohl, T., Bächler, D., and Rybach, L.: Steps towards a comprehensive thermo-hydraulic analysis of the HDR test site Soultz-sousForêts, Proceedings World Geothermal Congress 2000, KyushuTohoku, Japan, 28 May-10 June 2000.

Kreuter, H.: Deep geothermal projects in Germany - status and future development, Paris, 5 April 2011, oral presentation, 5 April 2011; retrieved from: http://www.renewablesb2b.com/data/ shared/GEO_PPT_Kreuter.pdf (last access: 17 March 2015), 2011a.

Kreuter, H.: Definition on EGS. http://egec.info/wp-content/ uploads/2011/08/3-TP-GEOELEC-PISA-Kreuter-.pdf (last access: 17 June 2014), 2011 b.

Kruger, P.: Heat extraction from Microseismic estimated geothermal reservoir volume, GRC Transactions, 14, Part II, 1225-1232, 1990.

Ladner, F. and Häring, M. O.: Hydraulic characteristics of the basel 1 enhanced geothermal system, GRC Trans. 33, 199-203, 2009.

Ledésert, B., Hebert, R., Genter, A., Bartier, D., Clauer, N., and Grall, C.: Fractures, hydrothermal alterations and permeability in the Soultz Enhanced Geothermal System, Compt. Rend. Geosci., 342, 607-615, 2010.

Lee, T. J., Song, Y., Yoon, W. S., Kim, K., Jeon, J., Min, K., and Cho, Y.: The first Enhanced Geothermal System Project in Korea. Proceedings of the 9th Asian Geothermal Symposium, 7-9 November 2011.

Lovelock, B.: Statement of the Updated Geothermal Reserves and Resources Estimates as at 31 October 2011, Green Rock Energy Ltd report, 2011.

Majer, E., Baria, R., Stark, M., Oates, S., Bommer, J., Smith, B., and Asanuma, H.: Induced seismicity associated with enhanced geothermal systems, Geothermics, 36, 185-222, 2007.

Meyer, G., Larking, A., Jeffrey, R., and Bunger, A.: Olympic Dam EGS Project. Proceedings World Geothermal Congress 2010, Bali, Indonesia, 25-29 April 2010.

MIT (Massachusetts Institute of Technology), Tester, J. W., Anderson, B. J., Batchelor, A. S., Blackwell, D. D., DiPippo, R., Drake, E. M., Garnish, J., Livesay, B., Moore, M. C., Nichols, K., Petty, S., Toksöz, M. N., and Veatch Jr., R. W.: The future of geothermal energy - impact of enhanced geothermal systems on the United States in the 21st Century, US Department of Energy, Washington, D.C., complete report, 2006a.

MIT (Massachusetts Institute of Technology), Tester, J. W., Anderson, B. J., Batchelor, A. S., Blackwell, D. D., DiPippo, R., Drake, E. M., Garnish, J., Livesay, B., Moore, M. C., Nichols, K., Petty, S., Toksöz, M. N., and Veatch Jr., R. W.: The future of geothermal energy - impact of enhanced geothermal systems on the United 
States in the 21st Century, US Department of Energy, Washington, D.C., 4-40, 2006 b.

MIT (Massachusetts Institute of Technology), Tester, J. W., Anderson, B. J., Batchelor, A. S., Blackwell, D. D., DiPippo, R., Drake, E. M., Garnish, J., Livesay, B., Moore, M. C., Nichols, K., Petty, S., Toksöz, M. N., and Veatch Jr., R. W.: The future of geothermal energy - impact of enhanced geothermal systems on the United States in the 21st Century, US Department of Energy, Washington, D.C., 4-22-4-26, 2006c.

MIT (Massachusetts Institute of Technology), Tester, J. W., Anderson, B. J., Batchelor, A. S., Blackwell, D. D., DiPippo, R., Drake, E. M., Garnish, J., Livesay, B., Moore, M. C., Nichols, K., Petty, S., Toksöz, M. N., and Veatch Jr., R. W.: The future of geothermal energy - impact of enhanced geothermal systems on the United States in the 21st Century, US Department of Energy, Washington, D.C., 4-37, 2006d.

MIT (Massachusetts Institute of Technology), Tester, J. W., Anderson, B. J., Batchelor, A. S., Blackwell, D. D., DiPippo, R., Drake, E. M., Garnish, J., Livesay, B., Moor,e M. C., Nichols, K., Petty, S., Toksöz, M. N., and Veatch Jr., R. W.: The future of geothermal energy - impact of enhanced geothermal systems on the United States in the 21st Century, US Department of Energy, Washington, D.C., 4-14-4-18, 2006e.

MIT (Massachusetts Institute of Technology), Tester, J. W., Anderson, B. J., Batchelor, A. S., Blackwell, D. D., DiPippo, R., Drake, E. M., Garnish, J., Livesay, B., Moore M. C., Nichols, K., Petty, S., Toksöz, M. N., and Veatch Jr., R. W.: The future of geothermal energy - impact of enhanced geothermal systems on the United States in the 21st Century, US Department of Energy, Washington, D.C., chapter 4.3, 4-7-4-13, $2006 f$.

MIT (Massachusetts Institute of Technology), Tester, J. W., Anderson, B. J., Batchelor, A. S., Blackwell, D. D., DiPippo, R., Drake, E. M., Garnish, J., Livesay, B., Moore, M. C., Nichols, K., Petty, S., Toksöz, M. N., and Veatch Jr., R. W.: The future of geothermal energy - impact of enhanced geothermal systems on the United States in the 21 st Century. US Department of Energy, Washington, D.C., 4-38, 2006g.

MIT (Massachusetts Institute of Technology), Tester, J. W., Anderson, B. J., Batchelor, A. S., Blackwell, D. D., DiPippo, R., Drake, E. M., Garnish, J., Livesay, B., Moore, M. C., Nichols, K., Petty, S., Toksöz, M. N., and Veatch Jr., R. W.: The future of geothermal energy - impact of enhanced geothermal systems on the United States in the 21 st Century. US Department of Energy, Washington, D.C., p. 4, 2006h.

Mortimer, L., Cooper, G., and Beardsmore, G.: As assessment of the Geothermal Energy Potential of Hot Sedimentary Aquifers (HSA). http://www.hotdryrocks.com/component/ option,com_docman/task,doc_download/gid,79/Itemid,71/ (last access: 17 June 2014), 2010.

Nag, P. K.: Power plant engineering, 3rd edition. Tata McGraw-Hill Publishing Company Limited, New Delhi, 2008.

Newberry EGS Demonstration: Stimulation and Microseismicity, 12 November 2014, http://blog.newberrygeothermal.com/, last access: 10 December 2014.

newworldenergy: Styles of geothermal energy. http: //newworldenergy.com.au/index.php/about-geothermal/ styles-of-geothermal-energy/, last access: 17 June 2014.

Orzol, J., Jung, R., Jatho, R., Tischner, T., and Kehrer, P.: The GeneSys-Project: Extraction of Geothermal Heat from Tight
Sediments. Proceedings World Geothermal Congress 2005, Antalya, 2005.

Panax Geothermal: Projects. Australia. Penola. http://www panaxgeothermal.com.au/projects-domestic-otway-penola.htm, last access: 27 May 2014.

Parker, R.: The Rosemanowes HDR project 1983-1991, Geothermics, 28, 603-615, 1999.

Pernecker, G.: Altheim geothermal plant for electricity production by ORC-turbogenerator, edited by: Peter. L., in: Bulletin d'hydrogéologie No 17. Centre d'Hydrogéologie. Université de Neuchâtel, Altheim, Austria, 1999.

Petratherm: Paralana, http://www.petratherm.com.au/projects/ paralana last access: 30 May 2014.

Pfalzwerke-geofuture: Projekt Insheim., http://www. geothermie-insheim.de/index.php/das-kraftwerk, last access: 29 May 2014.

PK Tiefe Geothermie: Nutzungen der geothermischen Energie aus dem tiefen Untergrund (Tiefe Geothermie) - Arbeitshilfe für Geologische Dienste, http://www.infogeo.de/dokumente/ download_pool/tiefe_geothermie_arbeitshilfe_08022007.pdf (last access: 17 June 2014), 2007.

Portier, S. and Vuataz, F.-D. (eds.): Studies and support for the EGS reservoirs at Soultz-sous-Forêts, final report April 2004May 2009, Project financed by State Secretariat for Education and Research (SER/SBF) and Swiss Federal Office of Energy (OFEN/BFE), 2009.

Portier, S., André, L., and Vuataz, F.-D.: Review on chemical stimulation techniques in oil industry and applications to geothermal systems. Technical report in enhanced geothermal innovative network for Europe, CREGE - Centre for Geothermal Research, Neuchâtel, 2007.

Potter, R., Robinson, E., and Smith, M.: Method of extracting heat from dry geothermal reservoirs, US Patent No. 3, 786-858, USA, Los Alamos, New Mexico, 1974.

Proactive Investors: Panax Geothermal study confirms commerciality of Penola Geothermal project to supply power. 20 August 2009, http://www.proactiveinvestors.com.au/companies/news/2322/ (last access: 27 May 2014), 2009.

RBS Morgans Ltd; retrieved from: http://newworldenergy.com.au/ wp-content/uploads/2010/02/RBS-Morgans-Research-Report. pdf (last accessed: 17 March 2015), 2009.

Reid, P. W. and Messeiller, M.: Paralana Engineered Geothermal Systems Project 3.5 MW Development Plan, Proceedings Australian Geothermal Energy Conferences 2013, Brisbane, Australia, 14-15 November 2013.

Rettenmaier, D. (): Lessons Learned - Reservoirmanagement Bruchsal., http://www.ta-survey.nl/pdf/GU2012-Detlev_ Rettenmaier.pdf (last access: 3 June 2014), 2012.

Richter, B.: Geothermal Energy Plant Unterhaching, Germany, Proceedings World Geothermal Congress 2010, Bali, Indonesia, 2529 April 2010.

Roberts, V. and Kruger, P.: Utility Industry Estimates of Geothermal Electricity - Geothermal power production to continue rapid growth through the year 2000, Geothermal Resources Council Bulletin, 7-10, 1982.

Romero Jr., A., McEvilly, T. V., Majer, E., and Vasco, D.: Characterization of the geothermal system beneath the Northwest Geysers 
Steam Field, California, from seismicity and velocity patterns, Geothermics, 24, 471-487, 1995.

Rutqvist, J., Dobson, P. F., Garcia, J., Hartline, C., Jeanne, P., Oldenburg, C. M., Vasco, D. V., and Walters, M.: The Northwest Geysers EGS Demonstration Project, California: Pre-stimulation Modeling and Interpretation of the Stimulation, Math. Geosci., 47, 3-29, 2013.

Sasaki, S.: Characteristics of microseismic events induced during hydraulic fracturing experiments at the Hijiori hot dry rock geothermal energy site, Yamagata, Japan, Tectonophysics, 289, $171-188,1998$.

Sass, I. and Goetz, A. E.: The thermofacies concept. Proceedings, Thirty-Sixth Workshop on Geothermal Reservoir Engineering, SGP-TR-191, Stanford University, Stanford, California, 31 January-2 February 2011.

Schanz, U., Stang, H., Tenzer, H., Homeier, G., Hase, M., Baisch, S., Weidler, R., Macek, A., and Uhlig, S. Hot dry rock project Urach - a general overview, in: Proceedings of the European geothermal conference, Szeged, 25-30 May 2003.

Schill, E., Genter, A. and Soultz team: EGS geothermal challenges within the Upper Rhine Valley based on the Soultz experience. Third European Geothermal Review (TEGR), Mainz, Germany, 24-26 June 2013.

Schindler, M., Baumgärtner, J., Gandy, T., Hauffe, P., Hettkamp, T., Menzel, H., Penzkofer, P., Teza, D., Tischner, T., and Wahl, G.: Successful Hydraulic Stimulation Techniques for Electric Power Production in the Upper Rhine Graben, Central Europe, Proceedings World Geothermal Congress 2010, Bali, Indonesia, 25-29 April 2010.

Schrage, C., Bems, C., Kreuter, H., Hild, S., and Volland, S.: Overview of the enhanced geothermal energy project in Mauerstetten, Germany, http://ta-survey.nl/pdf/120213_Geothermie_ Update_EGS_Mauerstetten.pdf (last access: 2 June 2014), 2012a.

Schrage, C., Bems, C., Kreuter, H., Hild, S., and Volland, S.: Geothermie Allgäu 2.0 - overview of the enhanced geothermal energy project in Mauerstetten, oral presentation held at Amsterdam, Germany, 18 April 2012, 2012 b.

Schulz, R.: Nutzung petrothermaler Technik - Vorschlag für eine Definition für die Anwendung des EEG, http://www. liag-hannover.de/fileadmin/produkte/20081126095553.pdf (last access: 17 June 2014), 2008.

Schulz, R.: Nutzung petrothermaler Technik - Entwurf 2.0. https://www.clearingstelle-eeg.de/files/private/active/0/GtV Bonus_EEG28-3-vers2.pdf (last access: 17 Ju8ne 2014), 2009.

Schumacher, S. and Schulz, R.: Effectiveness of acidizing geothermal wells in the South German Molasse Basin, Geoth. Energ. Sci., 1, 1-11, 2013.

Smith, M.: Southampton Energy Scheme - Proceedings World Geothermal Congress 2000, Kyushu-Tohoku, Japan, 28 May-10 June 2000.

Sonnenthal, E., Spycher, N., Callahan, O., Cladouhos, T., and Petty, S.: A Thermal-Hydrological-Chemical Model for the Enhanced Geothermal System Demonstration Project at Newberry Volcano, Oregon. Proceedings, Thirty-Seventh Workshop on Geothermal Reservoir Engineering, SGP-TR-194, Stanford University, Stanford, California, 30 January-1 February 2012.
Southampton: Geothermal and CHP scheme, http://www. southampton.gov.uk/s-environment/energy/Geothermal/ (last access: 27 May 2014), 2014a.

Southampton: Southampton District Energy Scheme Features, http://www.southampton.gov.uk/Images/ SouthamptonDistrictEnergySchemeFeatures_tcm46-314480.pdf (last access: 27 May 2014), 2014b

Southampton: Southampton Geothermal Well in Use, http://www.southampton.gov.uk/Images/ Southampton-Geothermal-Diagram_tcm46-305517.jpg (last access: 27 May 2014), 2014c.

Southampton: SGHC network facts 2011, http://www.southampton. gov.uk/s-environment/energy/Geothermal/ (last access: 27 May 2014), 2014d.

Stephens, J. C. and Jiusto, S.: Assessing innovation in emerging energy technologies: socio-technical dynamics of carbon capture and storage (CCS) and enhanced geothermal systems (EGS) in the USA, Energ. Pol., 38, 2020-2031, 2010.

Stibitz, M., Jiráková, H., and Frydrych, V.: Deep geothermal exploration drilling in the Bohemian massif (Litoměrice, Czech Republic). 1st Sustainable Earth Sciences Conference \& Exhibition - Technologies for Sustainable Use of the Deep Sub-surface, Valencia, Spain, 8-11 November 2011.

Sverrisson, H., Gudlaugsson, S. Th., Holm, S. L., Ingason, K., Tolnai, Z., Adam, L., Albertsson, O., and Tryggvadottir, L.: Case Study of an EGS Power Plant in Southern Hungary. European Geothermal Congress 2013, Pisa, Italy, 3-7 June 2013.

Tenzer, H.: Development of hot dry rock technology, GHC Bulletin, December, 2001.

Tenzer, H., Schanz, U., and Homeier, G.: HDR research programme and results of drill hole Urach 3 to depth of $4440 \mathrm{~m}$ - the key for realisation of a HDR programme in Southern Germany and Northern Switzerland. In: Proceedings of the world geothermal congress, Kyushu, Tohoku, 25-30 April 2000.

Tester, J. W., Brown, D. W., and Potter, R. M.: Hot dry rock geothermal energy - a new energy agenda for the 21st century, Los Alamos National Laboratory report, LA-11514-MS, US Department of Energy, Washington D.C., 1989.

Tischner, T., Evers, H., Hauswirth, H., Jatho, R., Kosinowski, M., and Sulzbacher, H.: New concepts for extracting geothermal energy from one well: the GeneSys-Project. In: Proceedings of the world geothermal congress, Bali, 25-30 April 2010.

Tischner, T., Kurg, S., Pechan, E., Hesshaus, A., Jatho, R., Bischoff, M., Wonik, T.: Massive Hydraulic Fracturing in Low Permeable Sedimentary Rock in the Genesys Project. In: Proceedings, Thirty-Eights Workshop on Geothermal Reservoir Engineering, SGP-TR-198, Stanford University, Stanford, California, 11-13 February 2013.

Torrens Energy: Projects, Parachilna. http://www2.torrensenergy. com/projects/parachilna.html, last access: 26 May 2014.

Tulinius, H., Correia, H. and Sigurdsson, O.: Stimulating a high enthalpy well by thermal cracking. - Proceedings, World Geothermal Congress, Japan, 1883-1887, 2000.

Tym, A.: City of Litoměřice Geothermal Project. EGEC Meeting, Brussels, 2 September 2011.

Tym, A.: Do have cities really a choice in planning sustainable energy future? 7th European Conference on Sustainable Cities \& Towns, Break-Out Session: Sustainable energy infrastructures: what role for cities?, Geneva, oral presen- 
tation; retrieved from: http://www.sustainablegeneva2013.org/ wp-content/uploads/2013/04/A10_Antonin-Tym.pdf (last access: 17 March 2015), 2013.

Urpi, L., Zimmermann, G., Blöcher, G., and Kwiatek, G.: Microseismicity at Groß Schönebeck - A Case Review. - PROCEEDINGS, Thirty-Sixth Workshop on Geothermal Reservoir Engineering, SGP-TR-191, Stanford University, Stanford, California, 31 January-2 February 2011.

VDI-Richtlinie 4640: Thermal use of the underground. Verein Deutscher Ingenieure-Gesellschaft Energie und Umwelt (GEU), Fachbereich Energiewandlung und -anwendung, Beuth Verlag GmbH, Berlin, 2010.

Wallroth, T., Eliasson, T., and Sundquist, U.: Hot dry rock research experiments at Fjällbacka, Sweden, Geothermics, 28, 617-625, 1999.

Walters, M.: Demonstration of an Enhanced Geothermal System at the Northwest Geysers Geothermal Field, CA. Geothermal Technologies Office 2013 Peer Review, Presentation hold at the April 2013 peer review meeting in Denver, Colorado, 2013.

Williams, C. F., Reed, J. J., and Anderson, A. F.: Updating the classification of geothermal resources, in: Proceedings of the thirtysixth workshop on geothermal reservoir engineering, Stanford University, Stanford, 31 January-2 February 2011.
Wyborn, D.: Hydraulic stimulation of the Habanero enhanced geothermal system (EGS), South Australia. Presentation held at the 5th BC unconventional gas technical forum, April 2011.

Zimmermann, G., Tischner, T., Legarth, B., and Huenges, E.: Pressure-dependent production efficiency of an enhanced geothermal system (EGS): stimulation results and implications for hydraulic fracture treatments, Pure Appl. Geophys., 166, 1089-1106, 2009.

Zimmermann, G., Moeck, I., and Blöcher, G.: Cyclic waterfrac stimulation to develop an enhanced geothermal system (EGS): Conceptual design and experimental results, Geothermics, 39, 59-69, 2010a.

Zimmermann, G., Reinicke, A., Blöcher, G., Moeck, I., Kwiatek, G., Brandt, W., Regenspurg, S., Schulte, T., Saadat, A., and Huenges, E.: Multiple Fracture Stimulation Treatments to Develop an Enhanced Geothermal System (EGS), Conceptual Design and Experimental Results, Proceedings World Geothermal Congress 2010, Bali, Indonesia, 25-29 April 2010, 2010 b. 